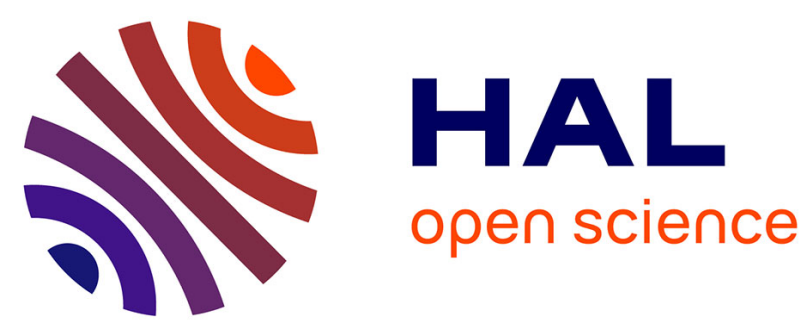

\title{
Mean surface circulation and mesoscale turbulent flow characteristics in the eastern South Pacific from satellite tracked drifters
}

Alexis Chaigneau, Oscar Pizarro

\section{> To cite this version:}

Alexis Chaigneau, Oscar Pizarro. Mean surface circulation and mesoscale turbulent flow characteristics in the eastern South Pacific from satellite tracked drifters. Journal of Geophysical Research, 2005, 110, pp.C05014. 10.1029/2004JC002628 . hal-00123741

\section{HAL Id: hal-00123741 \\ https://hal.science/hal-00123741}

Submitted on 1 Apr 2021

HAL is a multi-disciplinary open access archive for the deposit and dissemination of scientific research documents, whether they are published or not. The documents may come from teaching and research institutions in France or abroad, or from public or private research centers.
L'archive ouverte pluridisciplinaire HAL, est destinée au dépôt et à la diffusion de documents scientifiques de niveau recherche, publiés ou non, émanant des établissements d'enseignement et de recherche français ou étrangers, des laboratoires publics ou privés. 


\title{
Mean surface circulation and mesoscale turbulent flow characteristics in the eastern South Pacific from satellite tracked drifters
}

\author{
Alexis Chaigneau \\ Centro de Investigación Oceanográfica en el Pacífico Sur-Oriental/Programa Regional de Oceanografía Física y Clima, \\ Universidad de Concepción, Concepción, Chile

\section{Oscar Pizarro} \\ Departamento de Geofísica/Centro de Investigación Oceanográfica en el Pacífico Sur-Oriental, Universidad de Concepción, \\ Concepción, Chile
}

Received 26 July 2004; revised 3 January 2005; accepted 24 February 2005; published 21 May 2005.

[1] Circulation of the eastern South Pacific region $\left(10^{\circ}-34^{\circ} \mathrm{S}, 70^{\circ}-100^{\circ} \mathrm{W}\right)$ was studied using drifting buoy trajectories from 1979 to 2003. Three different current regimes were highlighted: the South Equatorial Current, flowing westward north of $26^{\circ} \mathrm{S}$ with surface velocities of $7-8 \mathrm{~cm} \mathrm{~s}^{-1}$; the South Pacific Current, an eastward current of $\sim 2 \mathrm{~cm} \mathrm{~s}^{-1}$ south of $25^{\circ}-30^{\circ} \mathrm{S}$; and the Chile-Peru Current, a northwestward flow of $\sim 6 \mathrm{~cm} \mathrm{~s}^{-1}$ found to the east of $82^{\circ} \mathrm{W}$ and south of $22^{\circ} \mathrm{S}$. The velocity variance distribution showed the regional flow to be anisotropic in nature. Maps of eddy kinetic energy obtained from drifter measurements and satellite altimetry data showed similar patterns, with higher energy levels near the South American coast. The Lagrangian time and length scales of the turbulent flow revealed typical values of $5.9 \pm 0.6$ days and $40.7 \pm 5.4 \mathrm{~km}$ in the zonal direction and of $3.5 \pm 0.4$ days and $29 \pm 3.4 \mathrm{~km}$ in the meridional direction. The estimated diffusivities were $(4.9 \pm 0.5) \times 10^{7} \mathrm{~cm}^{2} \mathrm{~s}^{-1}$ and $(2.6 \pm 0.3) \times 10^{7} \mathrm{~cm}^{2} \mathrm{~s}^{-1}$ in the eastward and northward directions, respectively. Finally, we estimated the respective role of horizontal advection and lateral diffusion on the mixed layer heat and salt budgets. Near the coast the lateral turbulent fluxes in the surface layer were two times larger than the horizontal transports associated with the large-scale circulation; mean horizontal heat and salt diffusive fluxes were around $25 \mathrm{~W} \mathrm{~m}^{-2}$ and $50 \mathrm{~g} \mathrm{~m}^{-2} \mathrm{~d}^{-1}$.

Citation: Chaigneau, A., and O. Pizarro (2005), Mean surface circulation and mesoscale turbulent flow characteristics in the eastern South Pacific from satellite tracked drifters, J. Geophys. Res., 110, C05014, doi:10.1029/2004JC002628.

\section{Introduction}

[2] Like other eastern boundary current systems, the eastern South Pacific is characterized by diffuse surface equatorward flows, part of the return flow of the windforced gyres. Near the continental coast, the Peru-Chile Current System is more complex and shows different currents flowing either northward or southward [Silva and Fonseca, 1983; Shaffer et al., 1995, 1997; Strub et al., 1998]. When superimposed on this horizontal circulation, persistent equatorward winds and the wind stress curl act together to drive intense upwelling of cold, deep water in this coastal region. The circulation and variability of the eastern South Pacific dynamics have been studied using altimetry measurements [Strub et al., 1995], historical observations [Pizarro, 1999; Blanco et al., 2001; Shaffer et al., 1997, 1999; Strub et al., 1998], and numerical models [Leth and Shaffer, 2001]. Nevertheless, detailed information about the regional surface circulation is still lacking. Another source of surface oceanic information is satellite-

Copyright 2005 by the American Geophysical Union. 0148-0227/05/2004JC002628 tracked drifting buoy data; its good spatial coverage allows this data set to be used for regional studies covering a broad range of scales, from large-scale flows to mesoscale eddy fields. Thus one of the goals of this paper is to give insight on the eastern South Pacific surface circulation, based on some 25 years of drifter measurements.

[3] As eddies are an important mechanism for the transport of heat, salt, and momentum and in order to better describe the oceanic features in the study region, an estimation of the lateral eddy diffusivity is also given. Different methods have been used in the last decade to estimate the diffusivity of the Pacific Ocean. For example, Stammer [1998] used satellite altimetry to show lateral diffusivity in the world ocean over a $5^{\circ} \times 5^{\circ}$ latitude-longitude grid, whereas Zhurbas and Oh [2003, 2004] used drifter data to describe diffusivity in both the Atlantic and Pacific oceans. The method used by these last authors is derived from the studies of Davis [1987, 1991]. Here we provide an independent estimation of lateral diffusivity based on Taylor's [1921] theory as well as Lagrangian statistics of the eastern South Pacific region $\left(10^{\circ}-34^{\circ} \mathrm{S}, 70^{\circ}-100^{\circ} \mathrm{W}\right)$. The important drifter data set allows us to estimate the velocity field and its variance, the eddy kinetic energy, the temporal and 
spatial decorrelation scales, and diffusivity, along with error estimates. We also determine the respective contributions of horizontal advection and turbulent diffusion on passive tracer fluxes. Mean advective and eddy diffusive temperature and salinity fluxes are thus estimated in the mixed layer of the whole study region. The ensemble of the results provides a useful tool for a comparison with the previous studies but also for the validation of both regional and global models in the eastern South Pacific.

[4] This work is organized as follows: section 2 describes the data sets and processing methods used; section 3 deals with the surface circulation and eddy kinetic energy; and section 4 analyses Lagrangian scales of variability and eddy diffusivity. In section 5, we estimate the respective role of the large-scale advection and turbulent diffusive flow on the mixed layer temperature and salinity fluxes. Finally, section 6 summarizes the study results.

\section{Data Set}

[5] The major data sets used in this study are surface satellite-tracked drifters and Topex-Poseidon/ERS1-2 altimeters measurements. Additionally, the World Ocean Atlas 2001 (WOA) climatology and satellite ERS winds are also used. The study region extends from $10^{\circ} \mathrm{S}$ to $34^{\circ} \mathrm{S}$ and from $70^{\circ} \mathrm{W}$ to $100^{\circ} \mathrm{W}$ (Figure $1 \mathrm{~b}$ ).

[6] The surface satellite-tracked drifters data set spans 1979-2003 and is part of the Global Drifter Program/ Surface Velocity Program. The drifters were equipped with a holey sock drogue centered at $15 \mathrm{~m}$ depth in order to reduce surface drag induced by both wind and waves. The expected drogue slip relative to the water is less than $2 \mathrm{~cm} \mathrm{~s}^{-1}$ for winds up to $20 \mathrm{~m} \mathrm{~s}^{-1}$ [Niiler and Paduan, 1995; Niiler et al., 1995]. The Atlantic Oceanographic and Meteorological Laboratory (AOML, Miami) received the drifter positions from Doppler measurements from Service ARGOS. These positions, irregularly distributed in time, were therefore quality controlled and interpolated to uniform 6 hour intervals using an optimum interpolation procedure [Hansen and Poulain, 1996]. Velocity components were calculated by a centered difference scheme at each 6 hour interval. In our study area, a total of 476 different drifters, able to exit and return to the area, were followed. To remove high-frequency tidal and inertial wave energy and to avoid aliasing the energy into the low-frequency motions, the four daily drifter data were averaged over 24 hour intervals [Swenson and Niiler, 1996; Martins et al., 2002]. A total of 72,244 daily buoy position and velocity data were thus obtained from 1979 to 2003 . Figure 1a shows the yearly distribution of the number of daily observations. In the study region for all the years between 1979 and 2003, the maximum amount of data were observed during the 1990s, corresponding to the World Ocean Circulation Experiment period, with a maximum of 9948 observations in 1993 and none in 1980 and 1984. The results did not differ significantly when considering data from the last decade (1991-2003) or the entire study period, although the number of degrees of freedom was decreased. In order to reduce the errors, we thus prefer use the whole drifter data set. All seasons of the year were equally sampled (not shown), with a minimum of around 15,000 observations in austral summer (January to March) and a maximum of 20,000 in austral spring (October to December). The results obtained hereafter are thus representative of an annual mean state. Figure $1 \mathrm{~b}$ shows the spatial coverage of the daily data (shading) in the study region, and the number of degrees of freedom or independent observations (see section 3.1 for calculation explanation). The bins have a minimum size of $2^{\circ} \times 2^{\circ}$ latitude-longitude and are adjusted, especially along the Chilean coast, to contain more than 6 independent observations. Only 33 of the 152 cells contained less than 20 independent data. The southwestern part of the region was extensively sampled, with more than 70 independent observations in each bin south of $24^{\circ} \mathrm{S}$ and west of $84^{\circ} \mathrm{W}$. In contrast, along the continental coast, the grid cells contain only between 6 and 35 degrees of freedom. For practical reasons, we have chosen 50 daily data or 6 independent observations as a lower limit, to make a compromise between reasonable grid cell dimensions and robustness of the results.

[7] The satellite altimetry data set used in this study is the gridded product of Topex/Poseidon, ERS-1/2, and Jason-1 sea level anomalies (SLA) provided by Archiving Validation and Interpretation of Satellite Data in Oceanography (AVISO). This data set spans 1993-2003, with weekly SLA distributed on a $1 / 3^{\circ}$ Mercator Grid. The methods used to process the data and reduce the errors are described by $L e$ Traon et al. [1995] and Le Traon and Ogor [1998] and by Ducet et al. [2000]. Zonal and meridional components of the residual sea surface velocity components were calculated from the SLA, using the geostrophic relationship

$$
\begin{gathered}
U_{g}^{\prime}=\frac{g}{f} \frac{\partial(\mathrm{SLA})}{\partial y} \\
V_{g}^{\prime}=-\frac{g}{f} \frac{\partial(\mathrm{SLA})}{\partial x},
\end{gathered}
$$

where $g$ is the acceleration due to gravity, $f$ is the Coriolis parameter, and $\partial x$ and $\partial y$ are the eastward and northward distances.

[8] Time mean eddy kinetic energy (per unit of mass), EKE, is calculated using

$$
\mathrm{EKE}=\frac{1}{2} \overline{\left(U_{g}^{\prime 2}+V_{g}^{\prime 2}\right)},
$$

where the overbar denotes time average.

[9] Monthly temperature and salinity climatologies on a $1 / 4^{\circ}$ latitude $\times 1 / 4^{\circ}$ longitude grid from the World Ocean Atlas were used to estimate surface geostrophic velocities relative to $1750 \mathrm{~m}$ depth. Generally, the common reference level is chosen at around $3500 \mathrm{~m}$ in the study region [Shaffer et al., 2004; Leth et al., 2004], but as this area is one of the least-sampled of the world oceans, the use of a climatology down to $3500 \mathrm{~m}$ may introduce important errors rather than improve our results. Furthermore, based on three hydrographic sections, Leth et al. [2004] show that the maximum horizontal velocity between $1750 \mathrm{~m}$ and $3500 \mathrm{~m}$ depth is less than $0.02 \mathrm{~cm} \mathrm{~s}^{-1}$ in the study area. Therefore we suppose that the $1750 \mathrm{~m}$ reference level does not introduce a significant error in the surface velocity calculation. In contrast to geostrophic velocities estimated from 
a)

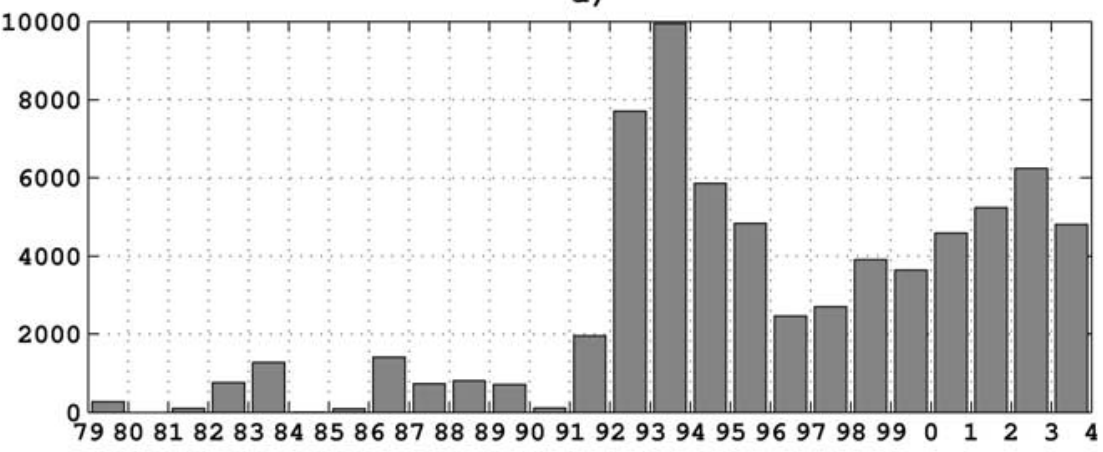

b)

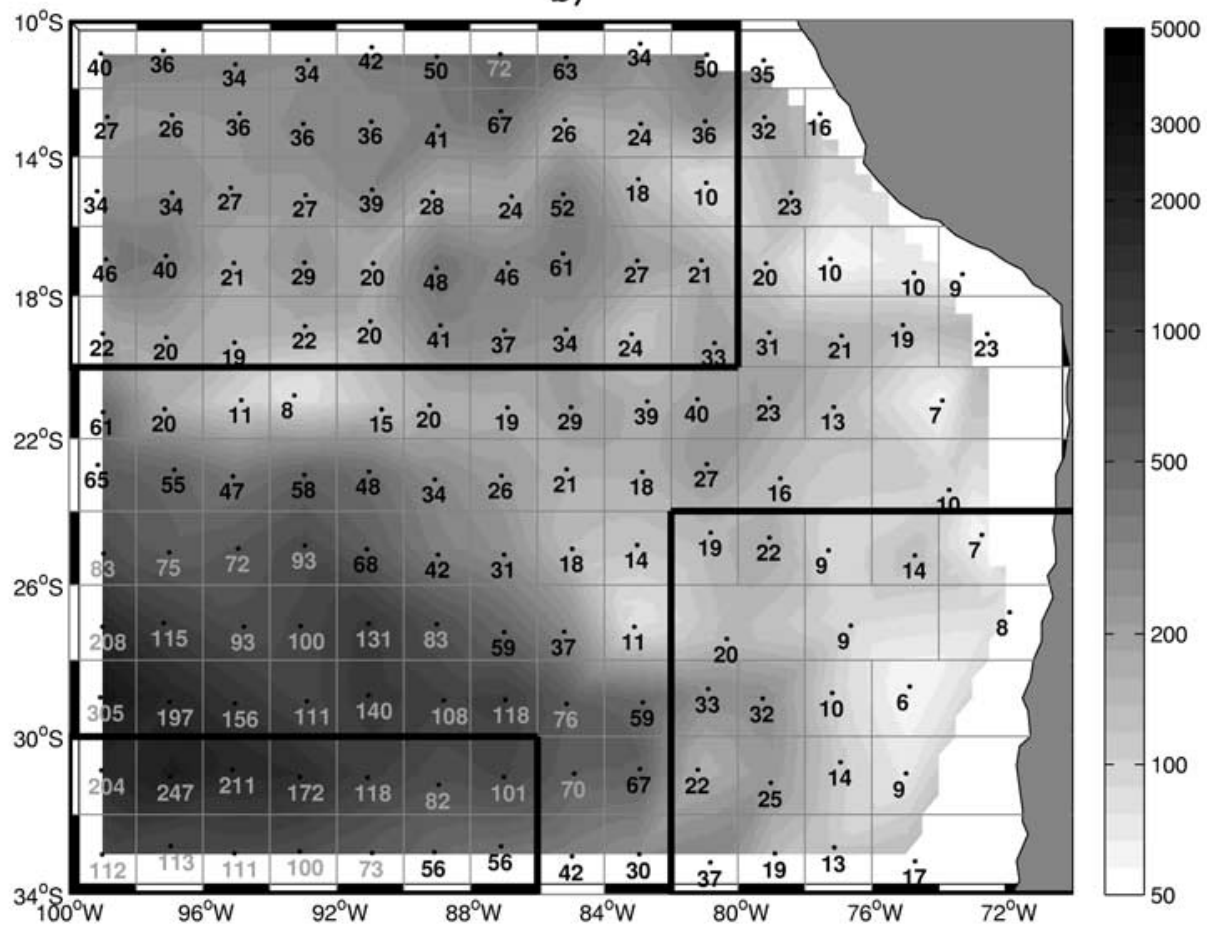

Figure 1. (a) Yearly distribution of buoy-day data from 1979 to 2003. (b) Spatial distribution of daily data (shading) and of buoy independent observations (numbers). The areas defined by bold lines correspond to the South Equatorial Current region $\left(10^{\circ}-20^{\circ} \mathrm{S}, 82^{\circ}-100^{\circ} \mathrm{W}\right)$, the South Pacific Current region $\left(30^{\circ}-34^{\circ} \mathrm{S}, 86^{\circ}-100^{\circ} \mathrm{W}\right)$, and the Chile-Peru Current region $\left(24^{\circ}-34^{\circ} \mathrm{S}, 70^{\circ}-82^{\circ} \mathrm{W}\right)$.

satellite altimetry, the velocity field obtained from hydrographic data includes the mean flow. To better interpret results from the drifters, surface Ekman velocities were estimated using weekly ERS1-2 wind stress on a $1^{\circ} \times 1^{\circ}$ latitudelongitude grids over the 1991-2001 period. Ekman transport was computed using

$$
\begin{gathered}
M_{x}=\frac{\tau_{y}}{\rho f} \\
M_{y}=-\frac{\tau_{x}}{\rho f},
\end{gathered}
$$

where $\left(M_{x}, M_{y}\right)$ are the horizontal components of the total Ekman transport, $\left(\tau_{x}, \tau_{y}\right)$ the $10 \mathrm{~m}$ wind stress components, $\rho$ the regional mean water density $\left(\rho=1024 \mathrm{~kg} \mathrm{~m}^{-3}\right)$, and $f$ the Coriolis parameter.

[10] The ageostrophic velocity components are then approximated by

$$
\begin{gathered}
U_{\mathrm{Ek}}=\frac{M_{x}}{D_{\mathrm{Ek}}} \\
V_{\mathrm{Ek}}=\frac{M_{y}}{D_{\mathrm{Ek}}},
\end{gathered}
$$

where $D_{\mathrm{Ek}}$ is the depth of the Ekman layer determined by [e.g., Cushman-Roisin, 1994]

$$
D_{\mathrm{Ek}}=\frac{0.4}{f} \sqrt{\frac{\tau}{\rho}},
$$


a)

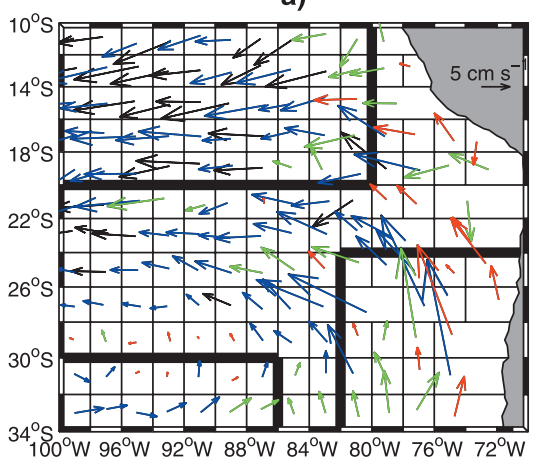

c)

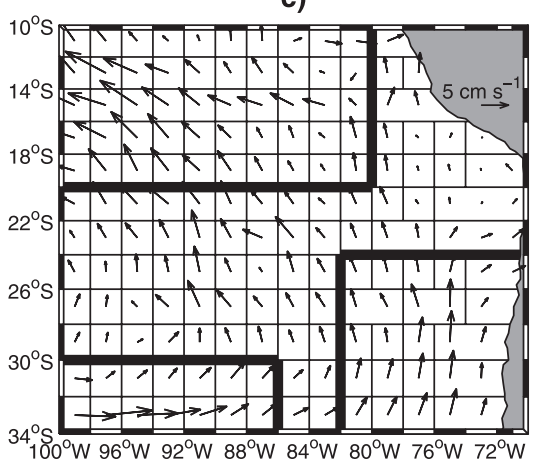

b)

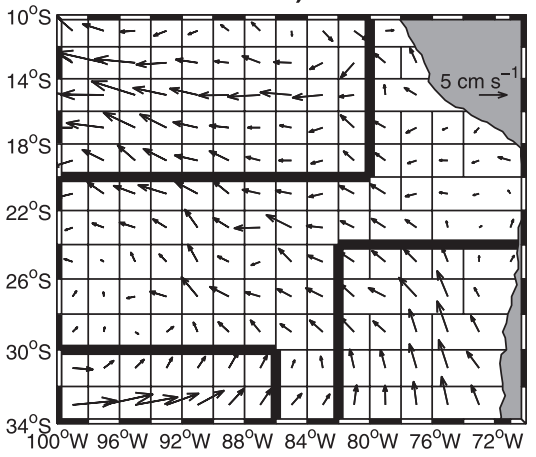

d)

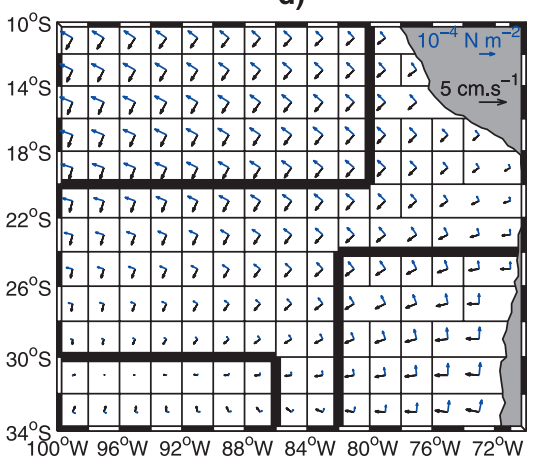

Figure 2. Mean surface circulation obtained from (a) satellite-tracked drifters, (b) the World Ocean Atlas (WOA) (2001) and Ekman velocities (see text), (c) the WOA only, and (d) Ekman velocities only (black arrows). The mean ERS wind stress from 1991 to 2001 is also plotted (blue arrows). The color code in Figure 2a corresponds to the relative velocity errors: black is less than 30\%, blue is between 30 and $50 \%$, green is between 50 and $80 \%$, and red is over $80 \%$. The arrow's origin is located at the average drifter position in each box. Bold lines show the SPC, SEC, and PCC.

where 0.4 is an empirical factor [Mofjeld and Lavelle, 1984; Stigebrandt, 1985]. According to this relationship, the estimated Ekman layer depth varies from 30-50 m south of $20^{\circ} \mathrm{S}$ to $100-130 \mathrm{~m}$ north of $14^{\circ} \mathrm{S}$. This crude Ekman layer depth estimation does not include the effect of stratification and overestimates the mixed layer depth principally in the North of the domain. Nevertheless, in the absence of other relevant information, we assume that the obtained underestimated velocities give at first order, a reasonable estimation of the surface layer wind driven motions.

\section{Surface Current Properties in the Eastern South Pacific}

\subsection{Surface Circulation}

[11] Assuming stationary statistics, the drifter velocity components were averaged in each spatial bin shown in Figure 1b. Figure 2a shows the large-scale surface circulation of the eastern South Pacific inferred from this data set. We note a relatively week eastward flow of $3-4 \mathrm{~cm} \mathrm{~s}^{-1}$ south of $32^{\circ} \mathrm{S}$, which is the signature of the eastern extension of the West Wind Drift [Strub et al., 1998; Vega, 2003] also called South Pacific Current (SPC) [Stramma et al., 1995; Tomczak and Godfrey, 1994]. As it flows toward the South American coast, part of this current is deflected northward to form the Chile-Peru Current (CPC). The CPC shows punctual velocities of $15-20 \mathrm{~cm} \mathrm{~s}^{-1}$ (Figure 2a). This current is also known as the Peru Current, Peru-Chile Current, and Humboldt Current [Wyrtki, 1964; Tomczak and Godfrey, 1994; Strub et al., 1998], but due to its south to north orientation, we prefer the name "Chile-Peru Current" introduced by Wooster [1970]. North of $25^{\circ} \mathrm{S}$, the surface coastal currents are weaker $\left(5-7 \mathrm{~cm} \mathrm{~s}^{-1}\right)$ and are oriented to the west/northwest to feed the broad branch of the South Equatorial Current (SEC) [Tomczak and Godfrey, 1994]. This region shows uniform westward flow driven by trade winds with typical values of $9-12 \mathrm{~cm} \mathrm{~s}^{-1}$ north of $20^{\circ} \mathrm{S}$. A more detailed analysis on a $1^{\circ} \times 1^{\circ}$ grid shows a southward flow closer to the coast. Even if this current can be associated with the Peru-Chile Countercurrent [Strub et al., 1998], the results remain inconclusive due to the insufficient amount of data and their irregular spatial and temporal distributions.

[12] The error $\Delta \mathbf{U}=(\Delta \mathrm{U}, \Delta \mathrm{V})$ of the mean velocities $\mathbf{U}=$ $(\mathrm{U}, \mathrm{V})$ was evaluated using Student's $t$ test with a significance level of $5 \%$ :

$$
\Delta \mathbf{U}=t_{N-1,0.025} \sqrt{\frac{\operatorname{var}(\mathbf{U})}{N^{*}}},
$$


Table 1. Statistics of the South Equatorial Current (SEC), the South Pacific Current (SPC), and the Chile-Peru Current (CPC), Obtained From Drifter Data and Calculated Surface Geostrophic and Ekman Velocities (WOA+ERS)

\begin{tabular}{|c|c|c|c|c|c|c|c|c|}
\hline & $N^{* \mathrm{a}}$ & $\bar{U} \pm \Delta U, \mathrm{~cm} \mathrm{~s}^{-1}$ & $\bar{V} \pm \Delta V, \mathrm{~cm} \mathrm{~s}^{-1}$ & $\overline{|\mathbf{U}|} \pm \Delta \mathbf{U}, \mathrm{cm} \mathrm{s}^{-1}$ & $\bar{u}^{\prime 2}, \mathrm{~cm}^{2} \mathrm{~s}^{-2}$ & $\bar{v}^{\prime 2}, \mathrm{~cm}^{2} \mathrm{~s}^{-2}$ & $\overline{u^{\prime} v^{\prime}}, \mathrm{cm}^{2} \mathrm{~s}^{-2}$ & $\overline{u^{\prime 2}} / \overline{v^{\prime 2}}$ \\
\hline \multicolumn{9}{|c|}{$\operatorname{SEC}\left(10^{\circ}-20^{\circ} \mathrm{S}, 80^{\circ}-100^{\circ} \mathrm{W}\right)$} \\
\hline Annual & 1342 & $-7.4 \pm 0.5$ & $-1.6 \pm 0.5$ & $7.6 \pm 0.4$ & 93.2 & 84.9 & 1.4 & 1.1 \\
\hline Summer & 295 & $-6.3 \pm 1.1$ & $-2.2 \pm 1.1$ & $6.6 \pm 1.0$ & 101.9 & 95.5 & 0.3 & 1.1 \\
\hline Fall & 364 & $-7.1 \pm 1.0$ & $-2.2 \pm 1.0$ & $7.4 \pm 0.8$ & 89.8 & 84.9 & 0.8 & 1.1 \\
\hline Winter & 357 & $-7.9 \pm 1.0$ & $-0.5 \pm 1.0$ & $7.9 \pm 0.8$ & 88.4 & 71.8 & 2.4 & 1.2 \\
\hline Spring & 418 & $-8 \pm 0.9$ & $-1.6 \pm 0.9$ & $8.1 \pm 0.8$ & 93.6 & 87.9 & 2.9 & 1.1 \\
\hline WOA+ERS & & -2.7 & 0.6 & 2.8 & & & & \\
\hline \multicolumn{9}{|c|}{$S P C\left(30^{\circ}-34^{\circ} \mathrm{S}, 86^{\circ}-100^{\circ} \mathrm{W}\right)$} \\
\hline Annual & 1431 & $1.7 \pm 0.6$ & $0.8 \pm 0.6$ & $1.9 \pm 0.4$ & 118.6 & 91.7 & -7 & 1.3 \\
\hline Summer & 387 & $-0.7 \pm 1.0$ & $0.3 \pm 1.0$ & $0.8 \pm 0.7$ & 99.3 & 73.5 & -6.1 & 1.4 \\
\hline Fall & 350 & $3 \pm 1.1$ & $1.5 \pm 1.1$ & $3.3 \pm 0.8$ & 118 & 88.7 & -7 & 1.3 \\
\hline Winter & 379 & $3.6 \pm 1.2$ & $0.9 \pm 1.2$ & $3.7 \pm 0.8$ & 134.2 & 109.1 & -12 & 1.2 \\
\hline Spring & 391 & $1.3 \pm 1.0$ & $0.7 \pm 1.0$ & $1.2 \pm 0.7$ & 112.7 & 95.2 & -5.5 & 1.2 \\
\hline WOA+ERS & & 3.4 & 1.7 & 3.8 & & & & \\
\hline \multicolumn{9}{|c|}{$C P C\left(24^{\circ}-34^{\circ} \mathrm{S}, 70^{\circ}-82^{\circ} \mathrm{W}\right)$} \\
\hline Annual & 277 & $-2.4 \pm 1.2$ & $5.4 \pm 1.2$ & $5.9 \pm 1.0$ & 110.4 & 108.7 & -15.2 & 1 \\
\hline Summer & 76 & $-3 \pm 2.2$ & $5.3 \pm 2.2$ & $5.9 \pm 1.8$ & 97.2 & 89.8 & -7.4 & 1.1 \\
\hline Fall & 55 & $-0.5 \pm 3.0$ & $3.4 \pm 3.0$ & $3.1 \pm 2.1$ & 120.9 & 72.6 & 5.5 & 1.7 \\
\hline Winter & 69 & $-1.1 \pm 2.5$ & $5.9 \pm 2.5$ & $5.8 \pm 2.2$ & 111.2 & 136.7 & -26.6 & 0.8 \\
\hline Spring & 96 & $-4 \pm 2.1$ & $6.3 \pm 2.2$ & $7.3 \pm 1.8$ & 108.1 & 119.7 & -21.3 & 0.9 \\
\hline WOA+ERS & & 0.4 & 2.8 & 2.8 & & & & \\
\hline
\end{tabular}

${ }^{\mathrm{a}}$ Number of independent observations.

where $t_{N-1,0.025}$ represents the Student's $t$ parameter, $\operatorname{var}(\mathbf{U})$ is the velocity variance, and $N^{*}$ the number of independent observations given by [Flierl and McWilliams, 1977]

$$
N^{*}=\frac{N \Delta t}{2 T}
$$

where $N$ is the number of daily observations, $\Delta t=1$ day is the sample rate, and $T=6$ days is the temporal decorrelation scale found in section 4.1. Using this method, we expect maximized error values, since the error variance is generally determined without multiplying it by Student's $t$ parameter [Flierl and McWilliams, 1977; Zhang et al., 2001].

[13] The relative velocity errors $(\Delta \mathbf{U} / \mathbf{U})$ are indicated by the colored arrows in Figure 2a. The relative error for more than $2 / 3$ of the surface velocities is less than $50 \%$ (black and blue arrows). Maximum errors are found where surface velocities are weaker than $1 \mathrm{~cm} \mathrm{~s}^{-1}$ (between $28^{\circ} \mathrm{S}$ and $32^{\circ} \mathrm{S}$ ) or along the coast, where the number of independent observations is small. In contrast, minimum errors are encountered in the north of the study area, where the number of independent observations is relatively high and the velocity variance relatively weak.

[14] Figure 2c shows the mean surface geostrophic velocities derived from dynamic heights calculated from the WOA (2001) hydrographic data. The geostrophic circulation does not reproduce the velocity field inferred from surface drifters; even if the geostrophic flow shows an eastward current associated with the SPC, the SEC exhibits a stronger northward component not observed in Figure 2a. Geostrophic velocities are weaker than $3-4 \mathrm{~cm} \mathrm{~s}^{-1}$ in all but the southwestern and northwestern sectors $\left(4-6 \mathrm{~cm} \mathrm{~s}^{-1}\right.$ and 6-9 $\mathrm{cm} \mathrm{s}^{-1}$, respectively). Undoubtedly, the ageostrophic part of the current plays an important role in surface circulation. Figure $2 \mathrm{~d}$ shows the mean ERS wind stresses (blue arrows) and the inferred Ekman velocities (black arrows). The wind field shows three main characteristics: a weak wind regime in the south western boundary of our study region, leading to Ekman velocities weaker than $1 \mathrm{~cm} \mathrm{~s}^{-1}$; an alongshore component, persistent year-round [Pizarro, 1999], which is upwelling favorable; north of $22^{\circ} \mathrm{S}$ and offshore, a north/northwest component leads to important south/southwest Ekman velocities of $2-2.5 \mathrm{~cm} \mathrm{~s}^{-1}$. The combination of mean geostrophic and ageostrophic velocities leads to a much better representation of the observed circulation from the drifters (Figure 2b). The inferred surface velocity directions are quite close to the observations with a continuous eastward flow north of $26^{\circ} \mathrm{S}$, and offshore flow near the coast. Although the direction of the mean currents is well-represented in Figure 2b, their magnitudes are weaker than that observed from drifters, except for the SPC. In the entire study area, the velocity modules are correlated at $40 \%$ at a significance level of $0.05 \%$, with a linear regression coefficient of 0.45 . The correlation is $47 \%$ in the SEC and $66 \%$ in the SPC, with regression coefficients of 0.52 and 1.43 . Coastal data for the $\mathrm{CPC}$ region is insufficient to determine significant correlations. Note that the correlation increases strongly considering only the zonal velocity component, with a value of $75 \%$ in the entire study domain and $80 \%$ in the SPC region. A more precise estimate of Ekman velocities could also increase the correlation, particularly in the SEC region, where the Ekman depth is overestimated.

[15] Table 1 gives the annual and seasonal averages of the SPC, SEC, and CPC properties obtained from the drifter data. In comparison, the annual average of the combination of geostrophic and wind induced surface velocities is also given (WOA+ERS, Table 1). The SEC is dominated by its strong westward velocity component $\left(7-8 \mathrm{~cm} \mathrm{~s}^{-1}\right)$, which is quite stable throughout the year. The minimum of $U=$ $-6.3 \mathrm{~cm} \mathrm{~s}^{-1}$ observed in austral summer (January to March) could be due to the reduced number of independent 
observations during this season (295 compared to 350$420)$, but also to the slight decrease of zonal wind stress intensity in the SEC region during the summer period (not shown). The velocity variance is quasi isotropic $\left(\sim 90 \mathrm{~cm}^{2}\right.$ $\mathrm{s}^{-2}$ ) with slightly higher variance along the zonal direction $\left(\overline{u^{\prime 2} / v^{\prime 2}}=1.1\right)$. In contrast, the southwestern box related to the SPC shows strong seasonal variability with an eastward flow of 3-4 $\mathrm{cm} \mathrm{s}^{-1}$ in fall (April to June) and winter (July to September), which decreases to $\sim 1 \mathrm{~cm} \mathrm{~s}^{-1}$ in spring (October to December) and reverses to a westward flow of $\sim 1 \mathrm{~cm} \mathrm{~s}^{-1}$ in summer. Even if the reversed current of $\sim 1 \mathrm{~cm} \mathrm{~s}^{-1}$ is not statistically significant and is on the order of the error (Table 1), a plot of the seasonal variability of the surface circulation (not shown) suggests meridional displacement of the southern limit of the SEC, with the westward current appearing between $30^{\circ} \mathrm{S}$ and $32^{\circ} \mathrm{S}$ during spring and summer, and between $26^{\circ} \mathrm{S}$ and $28^{\circ} \mathrm{S}$ in fall and winter. These oceanic seasonal variations are directly linked to the annual meridional displacement of the atmospheric high-pressure center of the eastern South Pacific, which migrates to the north during fall and winter. The seasonal wind stress calculated with the ERS data (not shown) in the same domain $\left(30^{\circ} \mathrm{S}-34^{\circ} \mathrm{S}\right.$ and $\left.86^{\circ} \mathrm{W}-100^{\circ} \mathrm{W}\right)$ shows stronger magnitudes in fall and winter $\left(0.1 \mathrm{~N} \mathrm{~m}^{-2}\right)$ than in spring and summer $\left(0.05 \mathrm{~N} \mathrm{~m}^{-2}\right)$. The SPC is anisotropic, with a $20-40 \%$ higher velocity variance along the zonal direction. The Chile-Peru Current shows a strong northward component, which is maximum in spring and minimum in fall. Again, this may be related to the wind regime because the satellite ERS measurements indicate stronger northward winds in this region between winter and summer $\left(0.05-0.06 \mathrm{~N} \mathrm{~m}^{-2}\right)$ than during fall $\left(0.035 \mathrm{~N} \mathrm{~m}^{-2}\right)$. On average, the CPC seems to be totally isotropic with a similar velocity variance of $110 \mathrm{~cm}^{2} \mathrm{~s}^{-2}$ in both zonal and meridional directions. On a seasonal scale, the data reveal strong anisotropy, for example, zonal variance is $70 \%$ stronger than its meridional counterpart in fall. This anisotropy could be linked to the Ekman transport, which indicates a zonal variance around $250 \%$ stronger than the meridional variance during this season (not shown).

[16] The quantification of the surface eddy momentum flux $\left(\overline{u^{\prime} v^{\prime}}\right)$ is important for understanding how eddies may act to transport momentum into or away from the mean flow [Morrow et al., 1992]. In the first place, the SEC and SPC can be considered to be zonal and the CPC meridional. In this case, the cross stream flux of along-stream momentum by transient eddies is given by $\overline{u^{\prime} v^{\prime}}$ [Wilkin and Morrow, 1994; Morrow et al., 1992, 1994]. For the westward SEC and eastward SPC, this term represents the meridional transfer of the zonal momentum, whereas for the equatorward CPC, it corresponds to the zonal transfer of meridional momentum. Owing to the mean westward (eastward, respectively) SEC (SPC), positive (negative) values of horizontal momentum flux (Table 1) correspond to a southward transport of the zonal momentum. The eddy flux momentum associated to the equatorward $\mathrm{CPC}$ is negative, with maximum values of around $-25 \mathrm{~cm}^{2} \mathrm{~s}^{-2}$ in austral winter and spring, revealing a westward transfer of the meridional momentum.

[17] Table 1 also shows that the velocities obtained using the climatology and satellite wind data (WOA+ERS) un- derestimate the South-Equatorial and Chile-Peru Currents and overestimate the South-Pacific Current. However, the directions of the SEC and SPC are well reproduced. In contrast, the intensity of the $\mathrm{CPC}$ is more than 2 times lower in the calculated velocities and the direction indicates a northward flow rather than an observed northwest current. These discrepancies may be induced by different factors, such as the coarse spatiotemporal resolution of the WOA climatology, or the Ekman velocity estimates, which are clearly underestimated in the northern part of the study region.

\subsection{Variance Ellipses}

[18] Velocity variance statistics were calculated from the drifter velocity components in each cell grid. From these data, we can compute the velocity variance terms $\left(\overline{u^{\prime 2}}, \overline{v^{\prime 2}}\right)$ and the covariance term $\left(\overline{u^{\prime} v^{\prime}}\right)$. Following the method used first by Freeland et al. [1975] in the North Atlantic ocean, the magnitude and the direction of the eddy variability are represented using variance ellipses [Preisendorfer, 1988; Morrow et al., 1992, 1994]. The formula giving the major and minor axes of principal variability can be found in Morrow et al. [1994] and Le Traon and Morrow [2001]. The direction of eddy momentum flux can be inferred from the ellipse orientation: negative $\overline{u^{\prime} v^{\prime}}$ correspond to ellipses oriented southeastward, whereas ellipses oriented toward the northeast quadrant have positive $\overline{u^{\prime} v^{\prime}}$ [Le Traon and Morrow, 2001].

[19] Velocity variance ellipses reveal the principal direction and anisotropic nature of the variability, as well as the magnitude and spatial distribution of the eddy energy. Figure 3 confirms the previous results that the flow tends to be nonisotropic in the most part of the domain and overall along the coast where the eddy kinetic energy is higher [Hormazabal et al., 2004]. In the SEC (SPC, relatively) region, the ellipses are oriented to the northeast (southeast), in agreement with the positive (negative) eddy momentum fluxes $\overline{u^{\prime} v^{\prime}}$ (Table 1). The southeast orientation of the ellipses in the CPC region also confirms the negative values of $\overline{u^{\prime} v^{\prime}}$ shown in Table 1.

\subsection{Eddy Kinetic Energy}

[20] The mean eddy kinetic energy per unit of mass is calculated in each bin from the drifter data using

$$
\mathrm{EKE}=\frac{1}{2} \overline{\left(u^{\prime 2}+v^{\prime 2}\right)}
$$

where the overbar denotes time average.

[21] The EKE is, on average, weaker in the SEC region defined in Table $1\left(87.7 \mathrm{~cm}^{2} \mathrm{~s}^{-2}\right)$ than in the SPC region $\left(103 \mathrm{~cm}^{2} \mathrm{~s}^{-2}\right)$ and $\mathrm{CPC}$ region $\left(112.7 \mathrm{~cm}^{2} \mathrm{~s}^{-2}\right)$. The mean kinetic energy $\left(\mathrm{MKE}=1 / 2\left(U^{2}+V^{2}\right)\right)$ is $2-3$ times smaller than the EKE in the SPC and CPC $\left(35.9 \mathrm{~cm}^{2} \mathrm{~s}^{-2}\right.$ and $44.9 \mathrm{~cm}^{2} \mathrm{~s}^{-2}$ ) and negligible in the $\mathrm{SEC}$ region $\left(4.1 \mathrm{~cm}^{2} \mathrm{~s}^{-2}\right)$.

[22] Despite the nonuniform character of the data, Figure $4 \mathrm{a}$ shows a decrease in EKE values from 200$300 \mathrm{~cm}^{2} \mathrm{~s}^{-2}$ along the continental coast to $50-100 \mathrm{~cm}^{2} \mathrm{~s}^{-2}$ in the interior ocean. We also note the presence of a local maximum of around $140 \mathrm{~cm}^{2} \mathrm{~s}^{-2}$ in the southwest boundary of the domain linked to the seasonal meridional 


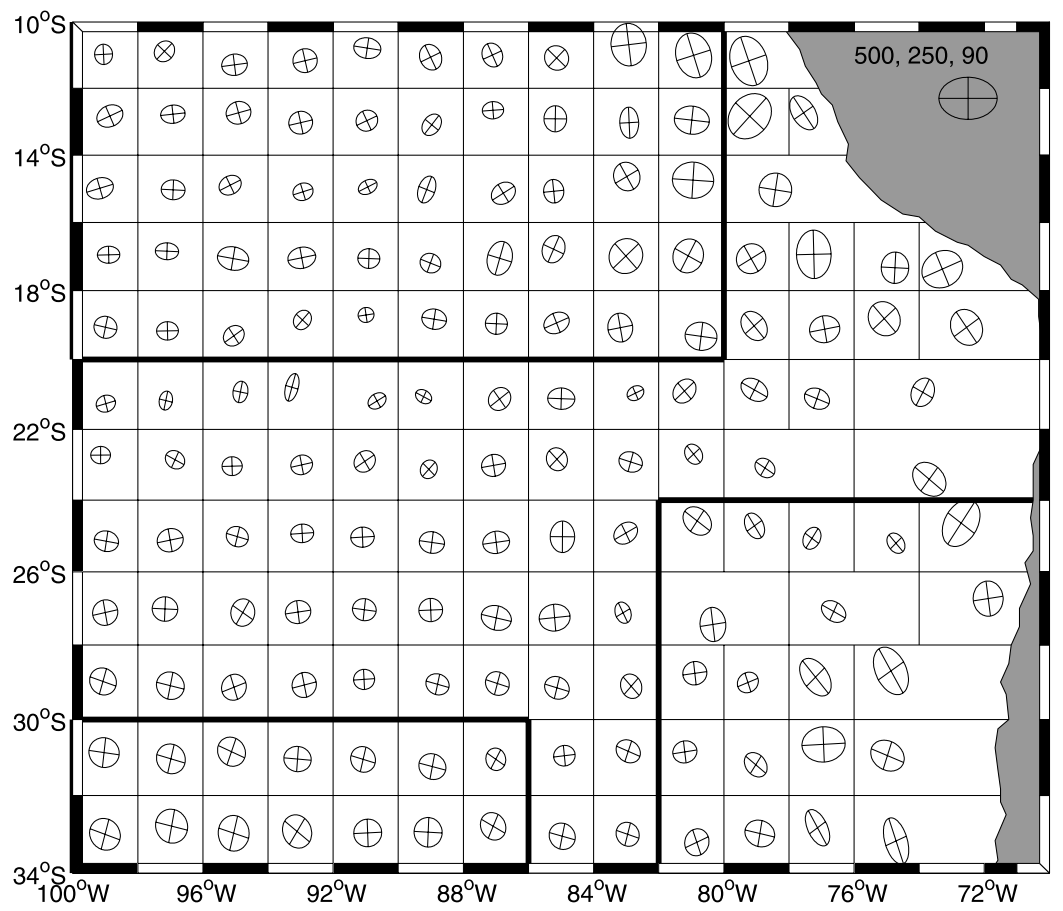

Figure 3. Velocity variance ellipses from drifter velocity components (see text). The ellipse's center is located at the average drifter positions in each box. The scale ellipse has a major axis of $500 \mathrm{~cm}^{2} \mathrm{~s}^{-1}$, a minor axis of $250 \mathrm{~cm}^{2} \mathrm{~s}^{-1}$, and is rotated $90^{\circ}$ from the north.

shift of the SPC. The maxima observed near the continent may be due to the interaction of the Peru-Chile Current System with the coastline. The strong upwelling front observed here during summer and spring could also contribute to generate baroclinic instabilities that increase mesoscale variability. Furthermore, coastal flow shows large intraseasonal and seasonal variability [Pizarro et $a l ., 2002]$ related to disturbances of equatorial origin that may reinforce the rather unstable coastal jet. On the other hand, downwelling phase Kelvin waves largely intensify the Peru-Chile Undercurrent [Shaffer et al., 1997], which may also destabilize the near-surface coastal circulation generating eddies. Such a mechanism has been proposed to explain the formation of eddies observed off the west coast of Mexico during El Niño periods [Zamudio et al., 2001]. Thus all these processes can act together to create strong instabilities responsible for the enhanced EKE along the coast.

[23] The EKE derived from satellite altimetry data (Figure $4 \mathrm{~b}$ ) confirms the distribution patterns obtained from the drifter data set, with maximum levels of EKE concentrated along the coast, but the magnitudes are about 2 times smaller. Differences between the two data sets are probably due to the fact that satellite data refers to the geostrophic components of the flow only, whereas the drifter EKE also includes the ageostrophic component (see section 3.1). Furthermore, the altimetry data are representative of the upper water column $(1000-1500 \mathrm{~m})$, whereas the drifter circulation is influenced by the dynamics of the first $15 \mathrm{~m}$. A number of additional processes, not well-resolved by satellite measurements, can take place in this shallower layer. The goal of the next section is thus to describe the Lagrangian properties of the mesoscale structures observed with the satellite-tracked drifters.

\section{Lagrangian Properties of the Eastern South Pacific}

[24] Stammer [1997] used satellite altimetry data to describe the mesoscale characteristics (length scales and timescales) and lateral diffusivity of the world ocean. Zhurbas and Oh [2003] used drifter data and Davis's [1987, 1991] approach, to give the Lagrangian scales of the horizontal turbulent flow of the whole Pacific ocean over a $5^{\circ} \times 5^{\circ}$ latitude-longitude grid. Here we use an independent and simpler method [Taylor, 1921] based on the integration of the Lagrangian velocity autocovariance function. This method has been tested with drifter observations in the North Atlantic region [Colin de Verdiere, 1983; Krauss and Böning, 1987; Martins et al., 2002], in the Northwest and tropical Pacific [Oh et al., 2000; Bauer et al., 1998, 2002], and in other eastern boundary current regions [Poulain and Niiler, 1989; Brink et al., 1991]. All these studies show that when stationary and homogeneous turbulence is considered, the drifter's dispersion is well modeled by Taylor's [1921] hypothesis. We thus expect that the same conclusions are also valid in our study region, based on the surface data set having high number of degrees of freedom (overall in the interior ocean).

\subsection{Lagrangian Scales of the Surface Turbulent Flow}

[25] In the ocean, the transport of passive tracers depends on an infinite number of scales of motion and assumptions are necessary to obtain simplified equations of motion for 
a)

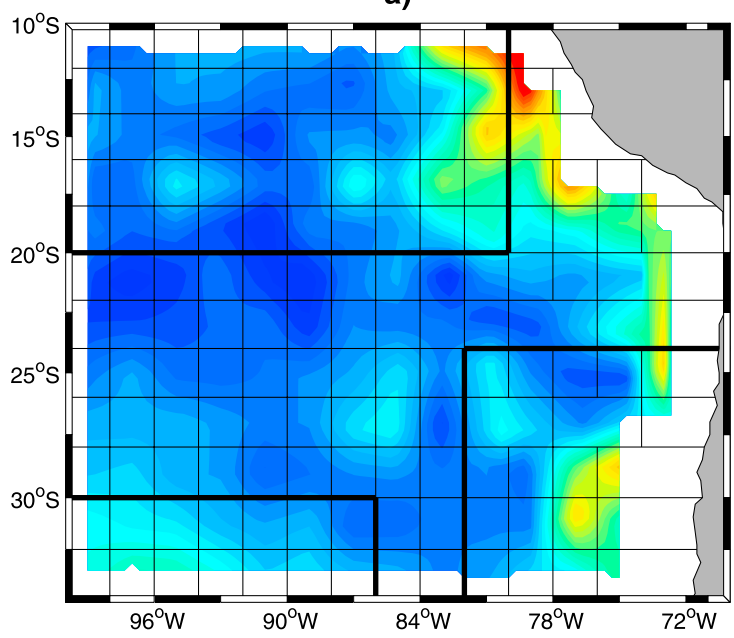

b)

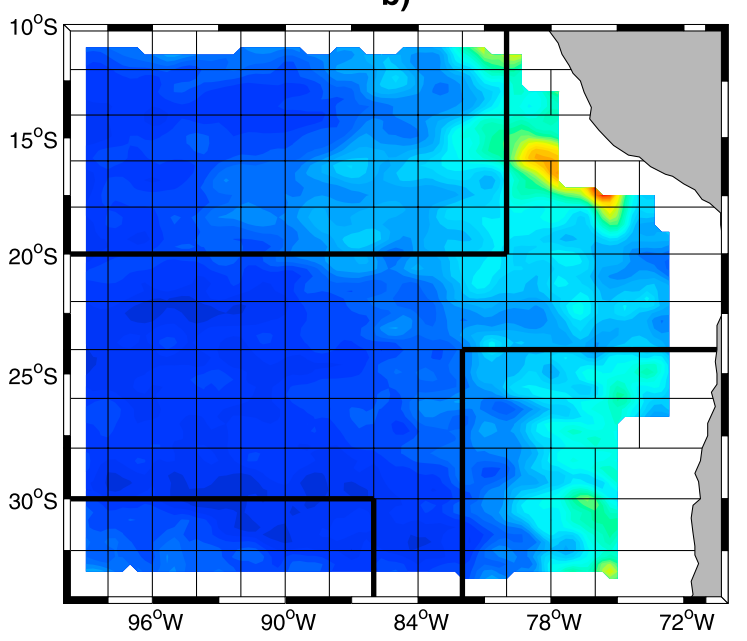

300

250

200

150 ก

100

50

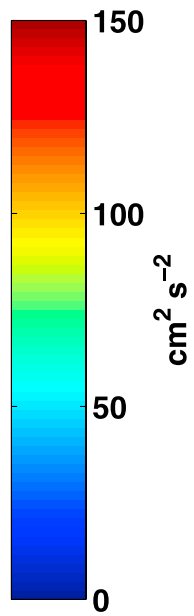

Figure 4. Spatial distribution of eddy kinetic energy from (a) drifter data and (b) satellite altimeter measurements of TP/ERS. Bold lines show the SPC, SEC, and PCC.

the tracer evolution. In a Lagrangian frame, the most common is that the velocity field can be decomposed in a mean flow $\overline{\mathbf{U}}=(\bar{U}, \bar{V})$ representative of large spatial scale, and in a turbulent mesoscale flow $\mathbf{u}^{\prime}=\left(u^{\prime}, v^{\prime}\right)$ computed following the fluid particles [Poulain and Niiler, 1989; Bauer et al., 1998, 2002; Kundu and Cohen, 2000]. Thus the mean current $\overline{\mathbf{U}}$ is determined by averaging the velocity components over each drifter trajectory. The main properties of the turbulent velocity field $\mathbf{u}^{\prime}$ are the Lagrangian integral time and length scales ( $\mathbf{T}$ and $\mathbf{L}$, respectively), which represents the time and the distance over which a particle remembers its path.

[26] For each component of the turbulent velocities $\left(u^{\prime}, v^{\prime}\right)$, we can determine a temporal scale $\mathbf{T}=\left(T_{u}, T_{v}\right)$ by integrating the respective velocity autocovariance function $\mathbf{R}=\left(R_{u}, R_{v}\right)$ to its first zero crossing $\Gamma$ [Taylor, 1921]:

$$
\mathbf{T}=\frac{1}{\mathbf{R}(0)} \int_{0}^{\Gamma} \mathbf{R}(\tau) d \tau .
$$

The Lagrangian autocovariance functions $R_{u}(\tau)=$ $\overline{u^{\prime}(t) u^{\prime}(t+\tau)}$ and $R_{v}(\tau)=\overline{v^{\prime}(t) v^{\prime}(t+\tau)}$ (here the overbar denotes ensemble average) were determined for each drifter spending more than 20 days in the domain and averaged in time. A total of 353 drifter trajectories, assumed to be independent, were then used to calculate this mean autocovariance function. If a drifter exits the area and returns several days later, the two different trajectories are considered distinctly. Figure 5a shows the mean autocovariance functions. The zonal and meridional components have an e-folding scale (time lag at which the normalized autocorrelation functions fall to $1 / e=0.368$ ) of 4.1 days and 3.7 days, respectively; their first zero crossings are 50 and 16 days.

[27] Figure 5b shows the integral timescales of the normalized autocovariance functions and indicates that the zonal components converge between 50 and 90 days and the meridional components between 15 and 25 days. After these periods, the autocorrelation functions still statistically converge to zero (Figure 5a), but as they are slightly 
a)

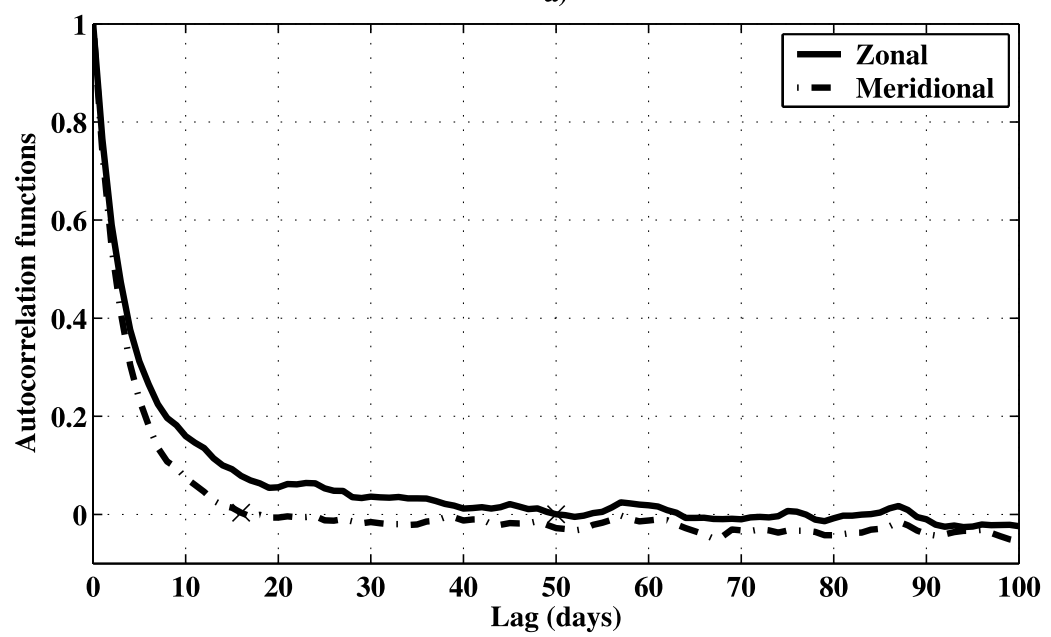

b)

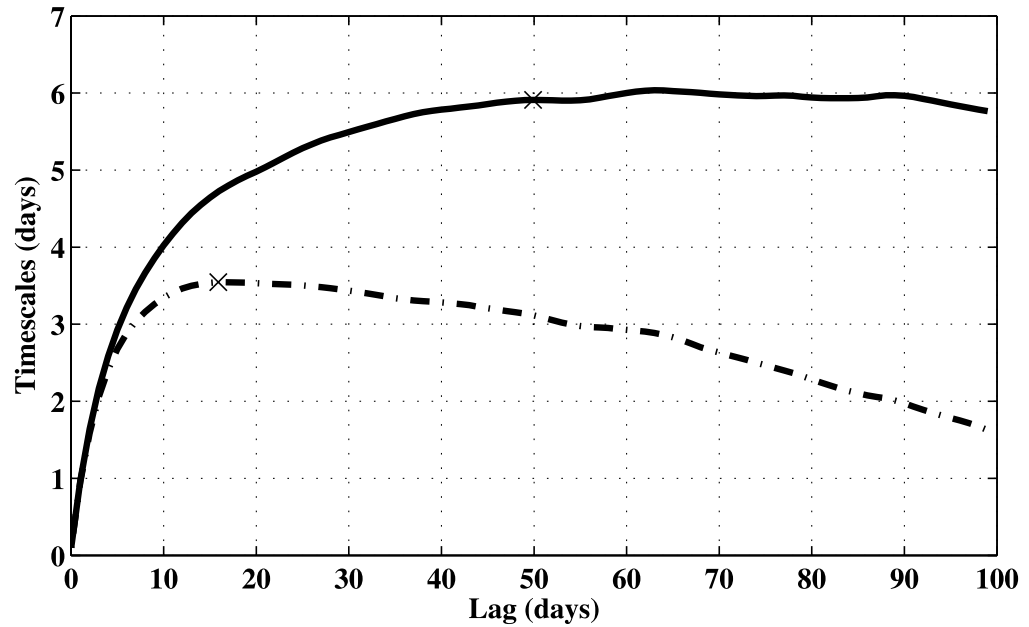

Figure 5. (a) Normalized mean time-lagged autocovariance functions for both velocity departure components based on the full drifter data set. (b) Estimates of the integral timescales $T_{u}$ and $T_{v}$. Crosses indicate the dates of the first zero crossing of both autocorrelation functions.

negative, the integral timescales decrease (Figure 5b). For this reason, timescales, which theoretically correspond to the integration of the normalized autocovariance functions to the infinite [Kundu and Cohen, 2000], are calculated only to the first zero crossing. This method is commonly used when $R$ is contaminated at large lags by noise and uncertainties in mean current [Richman et al., 1977; Poulain and
Niiler, 1989; Stammer, 1997, 1998; Lumpkin and Flament, 2001]. The obtained zonal and meridional timescales reveal the nonisotropic nature of the flows with values of 5.9 days and 3.5 days, respectively (Table 2). On the basis of a Student's $t$ test, with a significance level of $5 \%$, we estimated the timescale errors to be less than 0.6 days and 0.4 days in both directions. These temporal scales of $3-$

Table 2. Lagrangian Time and Length Scales, Velocity Variances, and Diffusivities for Both Zonal and Meridional Directions ${ }^{\mathrm{a}}$

\begin{tabular}{|c|c|c|c|c|c|c|c|c|}
\hline & $\mathrm{T}_{u}$, days & $T_{v}$, days & $L_{u}, \mathrm{~km}$ & $L_{v}, \mathrm{~km}$ & $\overline{u^{\prime 2}}, \mathrm{~cm}^{2} \mathrm{~s}^{-2}$ & $\overline{v^{\prime 2}}, \mathrm{~cm}^{2} \mathrm{~s}^{-2}$ & $K_{u}, 10^{7} \mathrm{~cm}^{2} \mathrm{~s}^{-1}$ & $\mathrm{~K}_{\mathrm{v}}, 10^{7} \mathrm{~cm}^{2} \mathrm{~s}^{-1}$ \\
\hline Global & $5.9 \pm 0.6$ & $3.5 \pm 0.4$ & $40.7 \pm 5.4$ & $29.0 \pm 3.4$ & 95.8 & 77.3 & $4.9 \pm 0.5(5)$ & $2.6 \pm 0.3(2.7)$ \\
\hline Global $^{b}$ & $6.5 \pm 0.3$ & $3.7 \pm 0.2$ & $38.9 \pm 2.0$ & $23.9 \pm 1.0$ & 87.3 & 65.5 & $4.9 \pm 0.3(4.8)$ & $2.1 \pm 0.2(2.3)$ \\
\hline $\mathrm{SEC}^{\mathrm{b}}$ & $4.8 \pm 0.4$ & $3.3 \pm 0.3$ & $24.7 \pm 2.9$ & $19.1 \pm 2.0$ & 75.0 & 61.8 & $3.1 \pm 0.3(2.7)$ & $1.8 \pm 0.2(1.9)$ \\
\hline $\mathrm{SPC}^{\mathrm{b}}$ & $3.1 \pm 0.2$ & $2.4 \pm 0.2$ & $19.5 \pm 1.8$ & $16.0 \pm 1.3$ & 99.2 & 77.2 & $2.7 \pm 0.2(2.4)$ & $1.6 \pm 0.2(1.6)$ \\
\hline $\mathrm{CPC}^{\mathrm{b}}$ & $3.3 \pm 0.8$ & $3.5 \pm 0.5$ & $24.1 \pm 4.7$ & $19.7 \pm 3.6$ & 77.2 & 60.4 & $2.2 \pm 0.5(2.5)$ & $1.8 \pm 0.4(2)$ \\
\hline
\end{tabular}

${ }^{\mathrm{a}}$ These were obtained from trajectories longer than 20 days. Each characteristic is given for the entire study region (Global), the SPC, SEC, and CPC. For the diffusivities the first number corresponds to the product of the variance and the Lagrangian timescale, whereas the second number (in parentheses) is obtained from the integration of the autocorrelation function (see text for details).

${ }^{b}$ Values obtained with reinitialized trajectories (see text for details). 
6 days are equivalent to those of the tropical Pacific [Bauer et al., 1998] and close to the 2-7 days observed in the California currents [Swenson and Niiler, 1996].

[28] Corresponding to the integral timescales, we can determine the integral length scales in each direction $\mathbf{L}=$ $\left(L_{u}, L_{v}\right)$ using [Taylor, 1921; Knudsen and Katz, 1958]

$$
\mathbf{L}=\sqrt{\overline{\mathbf{u}^{\prime 2}}} \cdot \mathbf{T},
$$

where $\sqrt{\overline{\mathbf{u}^{\prime 2}}}$ represents the standard deviation of the turbulent flow velocity. The mean Lagrangian length scales and the associated errors determined by Student's $t$ test, with a significance level of $5 \%$, are $40.7 \pm 5.4 \mathrm{~km}$ for the zonal direction and $29 \pm 3.4 \mathrm{~km}$ for the meridional direction (Table 2), again showing the anisotropic nature of the study region. In the California Current region, Swenson and Niiler [1996] estimate typical space scales of 16-59 km. Depending on the subregion of the California Current Systems, the turbulent flow can show elongated time and length scales along both the zonal and meridional directions [Swenson and Niiler, 1996]. In this study, we have also shown the anisotropic character of the surface ocean in the eastern South Pacific; on average, both temporal and spatial scales were elongated in the zonal direction.

\subsection{Lateral Dispersion and Diffusivity}

[29] The large mixing rate in a turbulent flow is due to the fact that the fluid particles gradually diverge from their initial location. Taylor [1921] has shown that, in steady and homogeneous turbulence without mean flow, the zonal and meridional particle dispersion $\sqrt{\overline{\mathbf{X}^{\prime 2}}}=\left(\sqrt{\overline{X^{\prime 2}}}, \sqrt{\overline{Y^{\prime 2}}}\right)$ from its origin can be related to the velocity autocorrelation function by [e.g., Kundu and Cohen, 2000; Zhang et al., 2001; Martins et al., 2002]

$$
\overline{\mathbf{X}^{\prime 2}(t)}=2 \cdot \overline{\mathbf{u}^{\prime 2}} \cdot t \cdot \int_{0}^{t}\left(1-\frac{\tau}{t}\right) \cdot \frac{\mathbf{R}(\tau)}{\mathbf{R}(0)} \cdot d \tau,
$$

where the overbar denotes ensemble average of individual particles and $\mathbf{X}^{\prime}=\left(X^{\prime}, Y^{\prime}\right)$ is the Lagrangian position inferred by $\mathbf{u}^{\prime}=\left(u^{\prime}, v^{\prime}\right)$. In practice, if the statistics are stationary, the ensemble average is replaced by an average in time.

[30] Figure 6a shows the zonal and meridional dispersion of the drifters due to both velocity components. If $t$ is small compared to the autocorrelation scales, the autocorrelation function $\mathbf{R}$ tends to $\mathbf{R}(0)$ (Figure $5 \mathrm{~b}$ ) and the initial dispersion increases linearly with time and is proportional to the intensity of turbulent fluctuations:

$$
\operatorname{rms}\left(\mathbf{X}^{\prime}\right)=\sqrt{\overline{\mathbf{X}^{\prime 2}}}=\sqrt{\mathbf{u}^{\prime 2}} \cdot t
$$

Figure 6a shows effectively that for $t<3$ days, the zonal and meridional dispersions increase linearly with time, and that for $t<8$ days, they exhibit the same characteristics.

[31] For a long time $t$,

$$
\operatorname{rms}\left(\mathbf{X}^{\prime}\right)=\sqrt{\overline{\mathbf{X}^{\prime 2}}}=\sqrt{2 \mathbf{u}^{\prime 2} \mathbf{T} \cdot t}
$$

where $\mathbf{T}=\left(T_{u}, T_{v}\right)$ is the integral timescale. Using $T_{u}=$ 5.9 days and $T_{v}=3.5$ days, Figure 6 a shows that the dispersion of the drifters are close to the "random walk" regime predicted by Taylor [1921] for lags between 10 and 100 days. This relationship has been also observed in other ocean basins [e.g., Zhang et al., 2001; Martins et $a l ., 2002]$. For times longer than 100 days, the number of data drops drastically (Figure 6b) from around 350 for short times to around 120 for a lag of 200 days, and we have less confidence in the particle dispersions showing a plateau. After 100 days, the turbulent flow has displaced the drifters an average of $320 \mathrm{~km}$ zonally and $200 \mathrm{~km}$ meridionally from their origins. This result is consistent with the anisotropic nature of the turbulent flow observed in our study region.

[32] The diffusivity $\mathbf{K}=\left(K_{u}, K_{v}\right)$ in a problem of turbulent dispersion corresponds to the rate at which the magnitude of $\mathbf{X}^{\prime}=\left(X^{\prime}, Y^{\prime}\right)$ increases with time and is given by [Martins et al., 2002; Kundu and Cohen, 2000]

$$
\mathbf{K}(t)=\frac{1}{2} \frac{d}{d t} \overline{\mathbf{X}^{\prime 2}}=\overline{\mathbf{u}^{\prime 2}} \int_{0}^{t} \frac{\mathbf{R}(\tau)}{\mathbf{R}(0)} d \tau .
$$

$\mathbf{K}$ is computed from the normalized autocorrelation functions and therefore the theoretical diffusivities are expected to converge to a constant value after some integral timescales T. Analyzing the two limit conditions

$$
\begin{gathered}
t \ll \mathbf{T}: \mathbf{K}(t) \approx \overline{\mathbf{u}^{\prime 2}} \cdot t \\
t \gg \mathbf{T}: \mathbf{K}(t) \approx \overline{\mathbf{u}^{\prime 2}} \cdot \mathbf{T},
\end{gathered}
$$

initially the diffusivity increases linearly with time, while for long times the diffusivity tends to a constant value depending on the integral timescale $\mathbf{T}$.

[33] The black lines in Figure 7 correspond to the diffusivities derived from the 353 independent drifter trajectories (section 4.1). The general forms of the curves are dominated by the form of the integrated normalized functions (Figure 5b), with a sharp increase for short times, followed by a plateau and then a decrease for longer times due to saturation and the negative values of the functions (Figure 5a). The product of the velocity variances by the integral timescales leads to $K_{u}=(4.9 \pm 0.5) \times 10^{7} \mathrm{~cm}^{2} \mathrm{~s}^{-1}$ and $K_{v}=(2.6 \pm 0.3) \times 10^{7} \mathrm{~cm}^{2} \mathrm{~s}^{-1}$ (Table 2). Averaging the diffusivity curves over the saturation plateau between $40-$ 70 days and 15-30 days in both zonal and meridional directions (bold black lines, Figure 7), we obtained, in the random walk regime, $K_{u}=5 \times 10^{7} \mathrm{~cm}^{2} \mathrm{~s}^{-1}$ and $K_{v}=2.7 \times$ $10^{7} \mathrm{~cm}^{2} \mathrm{~s}^{-1}$, in the range of the preceding error values.

[34] To increase the realizations and the number of degrees of freedom, we reinitialized the trajectories every 30 days (this value is much longer than the 3-6 day decorrelation timescale), as done in previous studies [Colin de Verdiere, 1983; Poulain and Niiler, 1989; Martins et al., 2002]. New autocorrelation functions (not shown) and diffusivities (gray lines, Figure 7) are determined for each velocity component. Although meridional diffusivity is slightly reduced by this procedure, the results are quite close to those obtained for the initial trajectories (Table 2). For the random walk regime $(t \gg \mathbf{T})$, and averaging over the same zonal and meridional plateaus (40-70 days and 

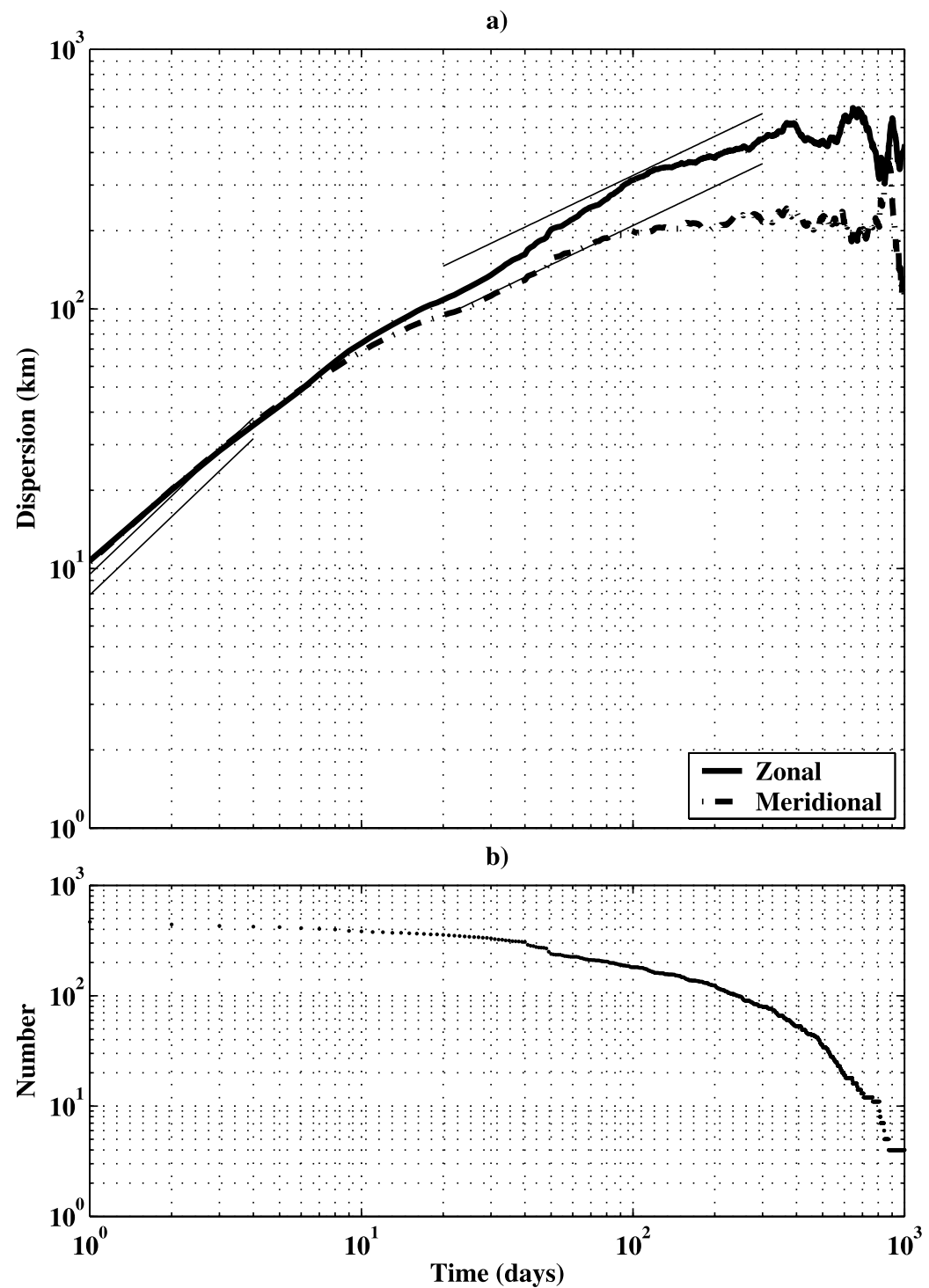

Figure 6. (a) Dispersion of the drifters as a function of time due to both velocity anomaly components and (b) the number of data used for the calculation. The scales are logarithmic and the straight lines in Figure 6a correspond to Taylor's [1921] asymptotes (see text).

15-30 days respectively), the reinitialized trajectories give $K_{u}=4.8 \times 10^{7} \mathrm{~cm}^{2} \mathrm{~s}^{-1}$ and $K_{v}=2.3 \times 10^{7} \mathrm{~cm}^{2} \mathrm{~s}^{-1}$. As the number of degrees of freedom was higher, we have more confidence in the values obtained from reinitialized trajectories, and in the next section, we use $K_{u}=4.8 \times$ $10^{7} \mathrm{~cm}^{2} \mathrm{~s}^{-1}$ and $K_{v}=2.3 \times 10^{7} \mathrm{~cm}^{2} \mathrm{~s}^{-1}$ to make initial calculations of horizontal, eddy heat, and salt fluxes in the mixed layer. These values agree with the results of Bauer et al. [2002], who estimated the maximum values of diffusivity in the SEC region (between $10^{\circ}-15^{\circ} \mathrm{S}$ and $100^{\circ}-160^{\circ} \mathrm{W}$ ) to be $4.8 \times 10^{7} \mathrm{~cm}^{2} \mathrm{~s}^{-1}$ and $2.8 \times 10^{7} \mathrm{~cm}^{2} \mathrm{~s}^{-1}$ in the zonal and meridional directions.

[35] Table 2 also shows the main turbulent flow characteristics (integral scales, velocity variances, diffusivities) of both the SEC, the SPC, and the CPC, calculated from reinitialized drifter trajectories in the corresponding subregion. The obtained diffusivities are on the order of $2.5-3 \times$ $10^{7} \mathrm{~cm}^{2} \mathrm{~s}^{-1}$ in the zonal direction and $1.5-2 \times 10^{7} \mathrm{~cm}^{2} \mathrm{~s}^{-1}$ in the meridional direction, with larger errors in the $\mathrm{CPC}$ region due to the limited number of drifter trajectories near the coast. The elongation in the mean flow direction, seen in the SEC and SPC (Table 2), is reduced in the northward CPC, which shows a higher temporal decorrelation scale in the meridional direction. In both the subareas, the diffusivity estimated through the integral of the autocovariance function and from the derivative of the dispersion function agree well.

\section{Heat and Salt Fluxes}

[36] What is the respective role of the turbulent flow and the mean current on the horizontal passive tracer fluxes in the surface layer of the eastern South Pacific? The answer is investigated by comparing the heat and salt fluxes due to both, horizontal advection by the large-scale currents and lateral diffusion by mesoscale circulation. The heat and salt 


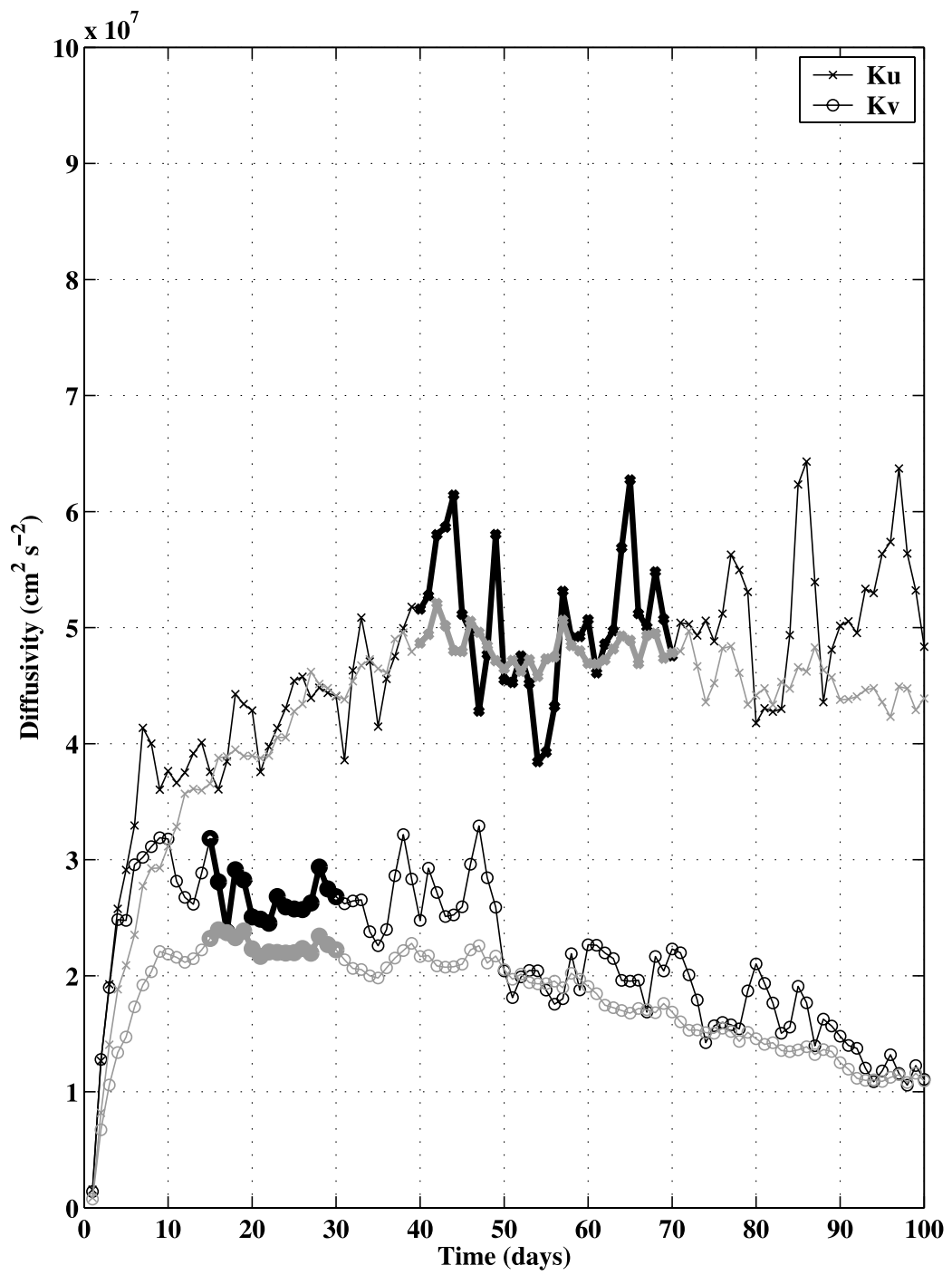

Figure 7. Estimates of the zonal and meridional components of eddy diffusivity in the whole region, based on the original (black lines) and reinitialized (shaded lines) drifter trajectories. The bold portions correspond to the periods where the diffusivities of the random walk regime are calculated.

fluxes due to the mean horizontal currents of the surface layer were calculated using

$$
\begin{aligned}
-\rho C_{p} H \mathbf{U} \cdot \operatorname{grad}(T) & =-\rho C_{p} H\left[U \frac{\partial T}{\partial x}+V \frac{\partial T}{\partial y}\right] \\
-\rho H \mathbf{U} \cdot \operatorname{grad}(S) & =-\rho H\left[U \frac{\partial S}{\partial x}+V \frac{\partial S}{\partial y}\right]
\end{aligned}
$$

where $T, S$, and $\rho$ are the WOA's mean surface temperature, salinity, and density; $H$ is the mixed layer depth fixed at $50 \mathrm{~m}$; $C_{p}$ is the specific heat of seawater (in $\mathrm{J} \mathrm{kg}^{-1} \mathrm{~K}^{-1}$ ); and $\mathbf{U}=$ $\left(U_{x}, U_{y}\right)$ is the sum of the mean surface geostrophic and Ekman velocities (Figure $2 b$ ). The surface property gradients are considered to be uniform over the constant mixed layer of $50 \mathrm{~m}$. This level corresponds approximately to the mixed layer depth observed in the region from hydrographic data [Blanco et al., 2001; Tsuchiya and Talley, 1998] or from WOA climatology (not shown).
[37] On the other hand, the horizontal heat and salt fluxes linked to the turbulent flow $\left(\mathbf{u}^{\prime}\right)$ are related to the transport divergences (div) by a parameterization of the mixing processes. We assume that, in a first approximation, the turbulent fluxes are proportional to and in direction of the downward property gradients. They are then represented by the eddy diffusivity coefficient $\mathbf{K}=\left(K_{u}, K_{v}\right)$, previously determined in the whole study region from reinitialized trajectories, and obey the commonly used Fickian law

$$
\begin{aligned}
-\rho C_{p} H \cdot \operatorname{div}\left(\mathbf{u}^{\prime} T^{\prime}\right) & =-\rho C_{p} H \cdot \operatorname{div}(-\mathbf{K} \nabla \mathbf{T}) \\
& =\rho C_{p} H \cdot\left[K_{u} \frac{\partial^{2} T}{\partial x^{2}}+K_{v} \frac{\partial^{2} T}{\partial y^{2}}\right] \\
-\rho H \cdot \operatorname{div}\left(\mathbf{u}^{\prime} S^{\prime}\right)= & -\rho H \cdot \operatorname{div}(-\mathbf{K} \nabla \mathbf{S}) \\
= & \rho H \cdot\left[K_{u} \frac{\partial^{2} S}{\partial x^{2}}+K_{v} \frac{\partial^{2} S}{\partial y^{2}}\right],
\end{aligned}
$$

with $K_{u}=4.8 \times 10^{7} \mathrm{~cm}^{2} \mathrm{~s}^{-1}$ and $K_{v}=2.3 \times 10^{7} \mathrm{~cm}^{2} \mathrm{~s}^{-1}$. 
a)

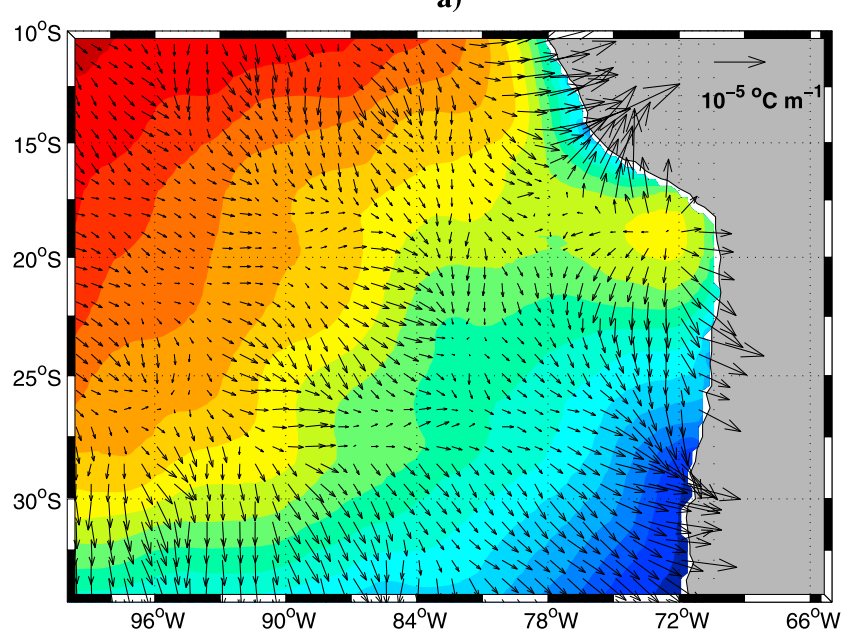

${ }^{\mathbf{o}} \mathbf{C}$

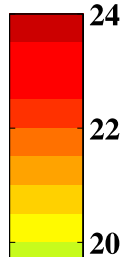

20

18

16

b)

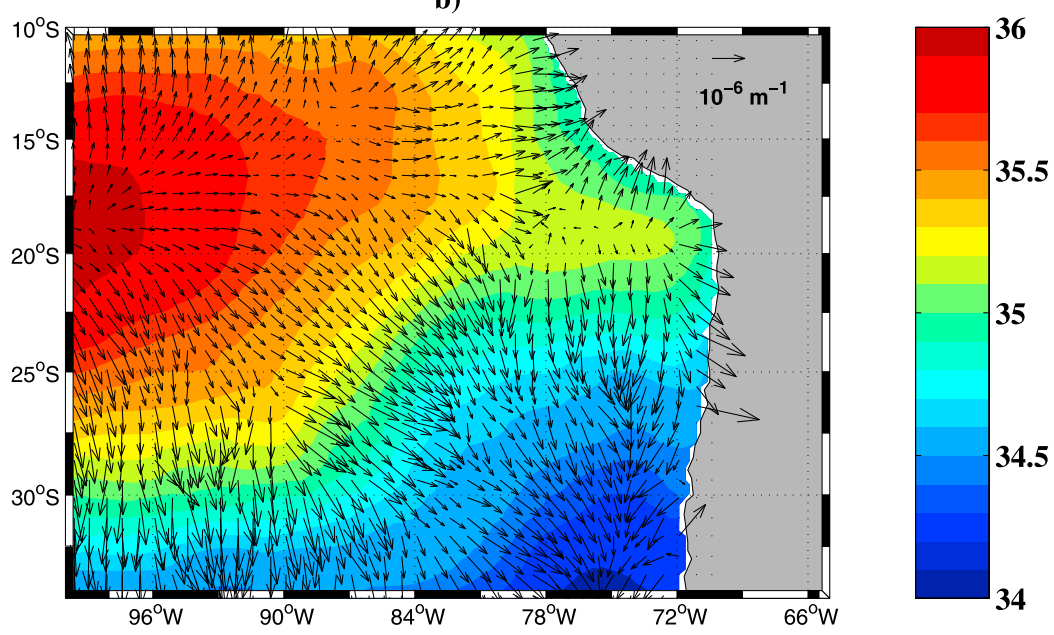

Figure 8. (a) Mean sea surface temperature and (b) sea surface salinity from the annual World Ocean Atlas (2001) climatology. The countergradient vectors are represented by arrows and indicate the direction of the horizontal diffusive transport (see text).

[38] Figure 8 shows the mean surface temperature and salinity fields of the WOA (2001), and the counter gradient vectors indicate the direction of the tracer transports induced by the turbulent flow. The surface temperature (Figure $8 \mathrm{a}$ ) is maximum in the northwest of the study region $\left(24^{\circ} \mathrm{C}\right)$ and minimum in the southeast (less than $14^{\circ} \mathrm{C}$ ). Along the coast, the northward wind regime produces upwelling of cold water into the surface layer, which leads to strong horizontal temperature gradients. The salinity distribution (Figure $8 \mathrm{~b}$ ) shows a patch of high salinities $(\sim 36)$ centered at $18^{\circ} \mathrm{S}-$ $98^{\circ} \mathrm{W}$ and fresher water along the coast with a minimum of around 34 in the southeastern limit of the study area. Therefore the counter temperature and salinity gradients and corresponding turbulent transports have principally southeastward orientations.

[39] Figure 9 shows the mean and turbulent horizontal temperature and salinity fluxes over the mixed layer. The diffusive heat flux variations average $\pm 15 \mathrm{~W} \mathrm{~m} \mathrm{~m}^{-2}$ in the study area (Figure 9a) but increase strongly near the coast, where turbulent fluxes reach more than $50 \mathrm{~W} \mathrm{~m}^{-2}$ locally. Mean horizontal surface layer currents, oriented principally northwestward (Figure 2b), transport cold water from higher latitudes into the study area. The resulting advective heat flux (Figure 9b) is mostly negative $\left(-10\right.$ to $\left.-50 \mathrm{~W} \mathrm{~m}^{-2}\right)$ except near the coast, where it can reach positive values of $20-40 \mathrm{~W} \mathrm{~m}^{-2}$. The coastal positive heat flux around $20^{\circ} \mathrm{S}$ and $75^{\circ} \mathrm{W}$ (Figure $9 \mathrm{~b}$ ) is due to advection of the patch of warmer water centered at $19^{\circ} \mathrm{S}$ and $73^{\circ} \mathrm{W}$ (Figure 8), whereas the positive advective heat flux along the coast at the study area's northern limit (Figure 9b) is linked to weak local eastward surface current (Figure 2b). On average, over the whole study area, the horizontal mesoscale turbulent flow provides heat to the surface layer at a rate of $4.4 \mathrm{~W} \mathrm{~m}^{-2}$, whereas the horizontal advection produces a loss of heat on the order of $11.5 \mathrm{~W} \mathrm{~m}^{-2}$. Horizontal salt turbulent flux (Figure $9 \mathrm{c}$ ) varies by around $\pm 100 \mathrm{~g} \mathrm{~m}^{-2} \mathrm{~d}^{-1}$ in the region. South of $18^{\circ} \mathrm{S}$, strong positive diffusive fluxes of $100-$ $150 \mathrm{~g} \mathrm{~m}^{-2} \mathrm{~d}^{-1}$ are also observed along the coast. The 

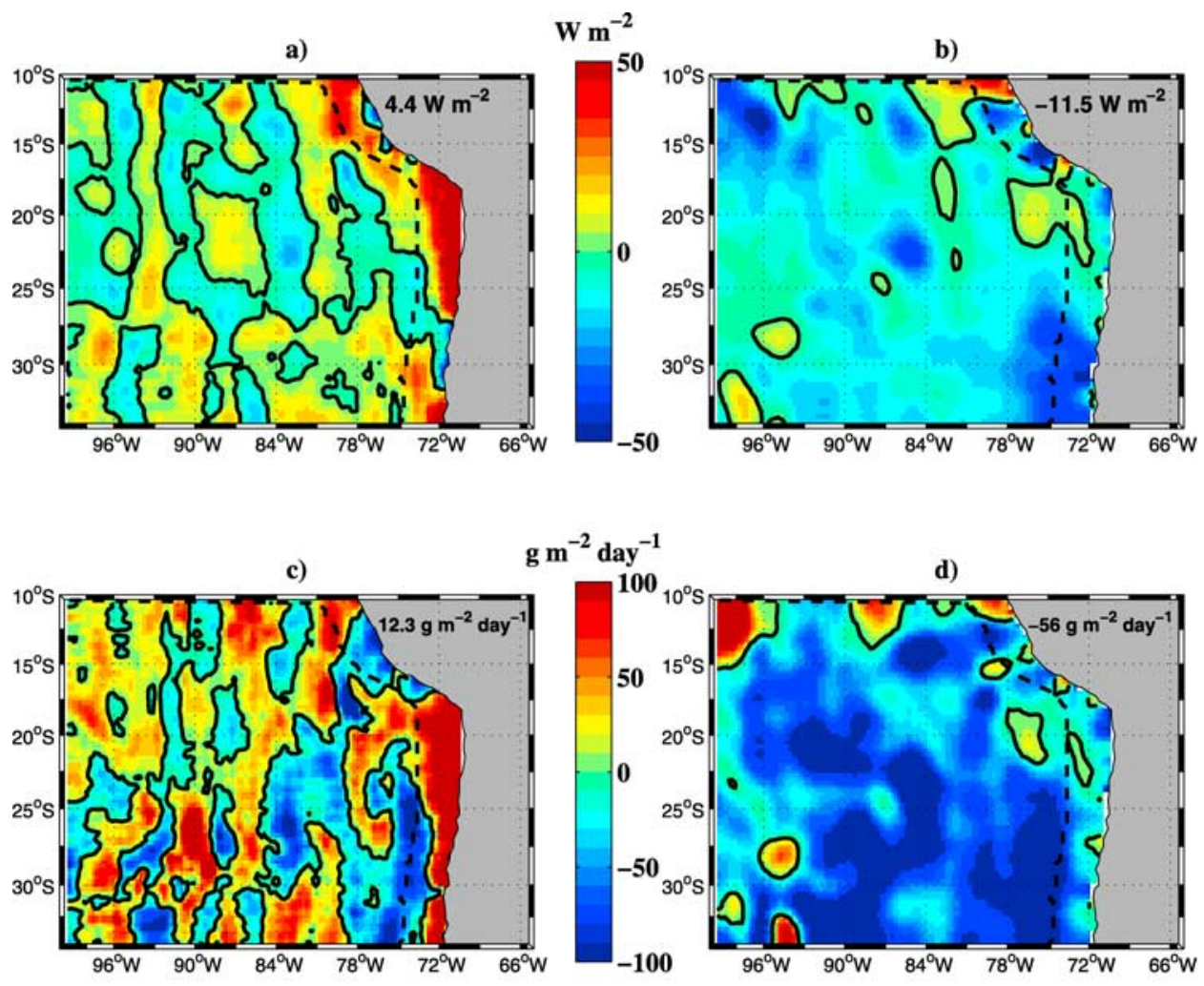

Figure 9. Horizontal $(\mathrm{a}, \mathrm{b})$ heat and $(\mathrm{c}, \mathrm{d})$ salt fluxes in the $50 \mathrm{~m}$ surface layer, associated with the (left) diffusive turbulent flow and with the (right) large-scale surface advection. Numbers indicated in black are the averages of the corresponding fluxes in the whole study region. The black dashed lines are situated $3^{\circ}$ offshore.

horizontal advective salt flux is highly negative $(<-50 \mathrm{~g}$ $\left.\mathrm{m}^{-2} \mathrm{~d}^{-1}\right)$ everywhere except locally, where patches of positive values are encountered. On average, the horizontal turbulent flow provides salt to the surface layer at a rate of $12.3 \mathrm{~g} \mathrm{~m}^{-2} \mathrm{~d}^{-1}$, whereas the horizontal advective flux freshens it at a rate of $-56 \mathrm{~g} \mathrm{~m}^{-2} \mathrm{~d}^{-1}$. The strong coastal horizontal heat and salt fluxes are due to important meridional temperature and salinity fronts (Figure 8) generated by the coastal upwelling of colder, fresher subsurface water.

[40] In order to better quantify the respective roles that advection and diffusion play in horizontal temperature and salinity mixed layer changes, Figure 10 shows the zonally averaged meridional variations of heat and salt fluxes between the coast and $3^{\circ}$ offshore. This cross-shore (perpendicular to the coast) turbulent heat flux is positive all along the coast with a mean value of around $25 \mathrm{~W} \mathrm{~m}^{2}$. In contrast, south of $12^{\circ} \mathrm{S}$, the horizontal advective heat flux associated with the mean currents is negative and cools the surface layer at a rate of $-15 \mathrm{~W} \mathrm{~m}^{2}$. Thus along the coast, the surface mesoscale turbulent flow totally counterbalances the cooling of the ocean surface by the mean horizontal large-scale circulation. Between $17^{\circ} \mathrm{S}$ and $27^{\circ} \mathrm{S}$, diffusive heat flux increases to $50 \mathrm{~W} \mathrm{~m} \mathrm{~m}^{2}$ and is the dominant horizontal oceanic process providing heat to the surface layer; the horizontal advective heat flux plays a minor role in this region. In terms of salt flux, advection and diffusion have an inverse relationship except north of $17^{\circ} \mathrm{S}$. On average, the coastal turbulent flow increases the salinity of the surface layer at a rate of around $50 \mathrm{~g} \mathrm{~m}^{2} \mathrm{~d}^{-1}$, whereas the advection of fresher water produces a negative salt flux on the order of $-30 \mathrm{~g} \mathrm{~m}^{2} \mathrm{~d}^{-1}$. Again, between $17^{\circ} \mathrm{S}$ and $27^{\circ} \mathrm{S}$, the salt flux due to mesoscale turbulence increased to $100-120 \mathrm{~g} \mathrm{~m}^{2} \mathrm{~d}^{-1}$.

[41] This section has principally shown that coastal lateral eddy fluxes in the mixed layer are around two times larger, in absolute value, than the horizontal transport associated with large-scale advection. However, the budget is not closed and other contributions, such as vertical advection and diffusion, entrainment, and outgoing solar fluxes at the base of mixed layer, may also play a significant role in the property evolutions. Furthermore, the results presented here are a crude estimate of the impact of lateral processes on the mixed layer temperature and salt changes. Some errors are certainly made by considering, for example, a homogeneous mixed layer of $50 \mathrm{~m}$ to be representative of the whole study area, or homogeneous diffusivities. Owing to the little hydrographic data available for the region, WOA climatology may have also introduced several biases into our calculations. Thus more estimates are needed, based for example on numerical simulations, to more precisely quantify the lateral fluxes due to both the large-scale advection and the turbulent flow in the study region.

\section{Summary and Conclusion}

[42] The goal of this study was to describe the mean surface circulation and the turbulent characteristics of the flow in the eastern South Pacific. On the basis of a 
a)

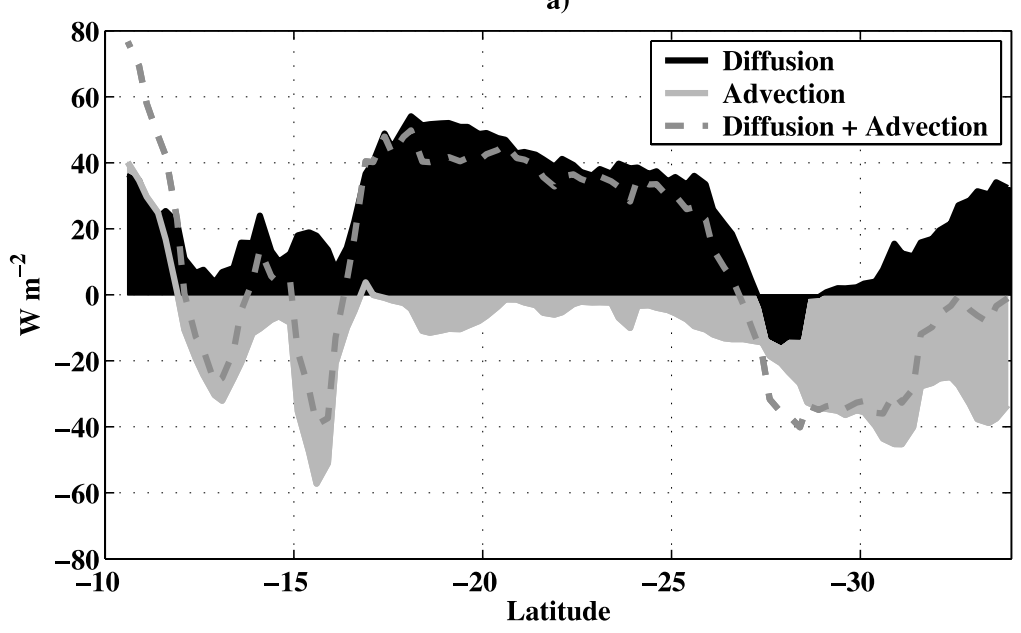

b)

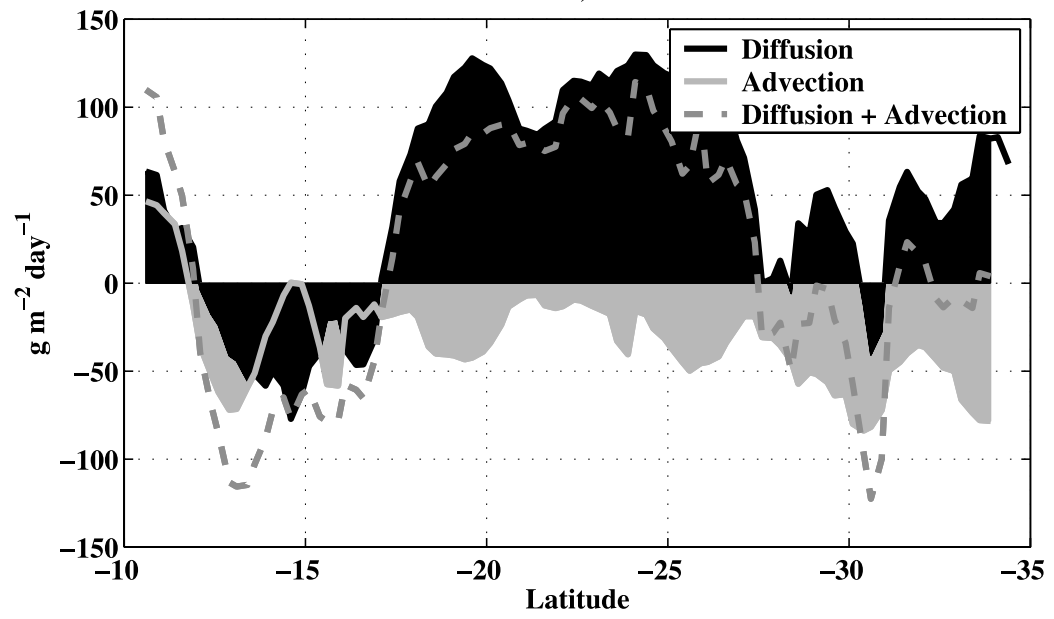

Figure 10. Mean horizontal (a) heat and (b) salt fluxes averaged between the coast and $3^{\circ}$ offshore (see Figure 9) as a function of latitude.

high coverage data from satellite-tracked drifter deployed throughout the 1979-2003 period, we have for the first time described quantitatively the large-scale current features in this region using Eulerian averages in geographical bins. Three main currents were studied: (1) the South Equatorial Current, flowing westward north of $26^{\circ} \mathrm{S}$ with surface velocities of $7-8 \mathrm{~cm} \mathrm{~s}^{-1}$ year-round; (2) the South Pacific Current, a slower eastward current of $\sim 2 \mathrm{~cm} \mathrm{~s}^{-1}$ south of $25^{\circ}-30^{\circ} \mathrm{S}$, which experiences strong seasonal variability related to the meridional movements of the subtropical anticyclone; and (3) the Chile-Peru Current, a stronger northeastward flow of $\sim 6 \mathrm{~cm} \mathrm{~s}^{-1}$ encountered east of $82^{\circ} \mathrm{W}$ and south of $24^{\circ} \mathrm{S}$, responding to local wind forcing. The Reynolds stresses (or the variance ellipses) related to these flows have principally revealed the anisotropic character of regional surface circulation. The eddy kinetic energies calculated from the drifter data and from the geostrophic velocities derived from the TP/ERS altimeters show similar patterns, with high energy levels along the continent and lower values in the interior ocean. On the other hand, the geostrophic EKE is around two times smaller than the values determined from the drifting-buoys.
[43] Lagrangian statistics were performed from the classical point of view of Taylor's [1921] theory, to evaluate in both the zonal and meridional directions, the integral time and space scales, the dispersion and the diffusivity. The turbulent flow shows time and length scales of $O(6$ days $)$ and $O(50 \mathrm{~km})$ with higher values along the zonal direction revealing the anisotropy of the region. The estimate of diffusivity through the derivative of the dispersion or via the integral of the autocovariance function gives essentially the same results, with higher values in the direction of the mean flow. Owing to the important number of independent observations, we expect that our diffusivity estimations are robust.

[44] Finally, we produced direct estimates of the horizontal heat and salt fluxes in the mixed layer due to both the mean horizontal advection and the lateral turbulent diffusion. On average, horizontal eddy fluxes in the study area provide heat $\left(\sim 5 \mathrm{~W} \mathrm{~m}^{-2}\right)$ and salt $\left(\sim 12 \mathrm{~g} \mathrm{~m}^{-2} \mathrm{~d}^{-1}\right)$ to the study region surface layer. These fluxes counterbalance the effect of the horizontal mean current, which advects colder and fresher water into the region. The magnitude of turbulent heat and salt fluxes in the study area are around 2 and 4 times smaller than advective fluxes. In contrast, along the 
coast, the mesoscale instabilities are a crucial mechanism of transport for warmer and saltier water into the upwelling region. In this zone, the horizontal turbulent heat and salt fluxes $\left(\sim 25 \mathrm{~W} \mathrm{~m}^{-2}\right.$ and $\left.\sim 50 \mathrm{~g} \mathrm{~m}^{-2} \mathrm{~d}^{-1}\right)$ are two times larger than the negative mean current advective fluxes. Thus in the Peru-Chile Current System, the horizontal fluxes associated with the mesoscale eddies can be significant in the long-term heat and salt budgets of the upper ocean. A comparison with net downward surface heat flux remains inconclusive, since the NCEP fluxes average around $-25 \mathrm{~W} \mathrm{~m}^{-2}$ annually, whereas the Southampton Oceanography Center (SOC) surface flux climatology indicates positive fluxes of around $25 \mathrm{~W} \mathrm{~m}^{-2}$ (not shown). Finally, other terms not considered in this study (e.g., vertical advection and diffusion, entrainment at the base of the mixed layer) could also play a significant role on the tracer budgets.

[45] This study has given insight into the mean surface circulation and mesoscale flow characteristics of the eastern South Pacific region. The results provide a useful measure for validating numerical models. In this poorly sampled region, more satellite buoy-tracked drifters and in situ measurements are also required to better understand the role of surface circulation on the heat and salt budget.

[46] Acknowledgments. Drifter data were provided by the National Oceanic and Atmospheric Administration (NOAA). The authors thank O. Leth, two anonymous reviewers, and editor James Richman for their helpful comments. A.C. was supported by ECOS-SUD and Fundación Andes grant D-13615. This work was also supported by the Chilean National Research Council (FONDAP-COPAS).

\section{References}

Bauer, S., M. S. Swenson, A. Griffa, A. J. Mariano, and K. Owens (1998), Eddy-mean flow decomposition and eddy-diffusivity estimates in the tropical Pacific Ocean: 1. Methodology, J. Geophys. Res., 103, $30,855-30,871$

Bauer, S., M. S. Swenson, and A. Griffa (2002), Eddy-mean flow decomposition and eddy-diffusivity estimates in the tropical Pacific Ocean: 2. Results, J. Geophys. Res., 107(C10), 3154, doi:10.1029/2000JC000613.

Blanco, J. L., A. C. Thomas, M.-E. Carr, and P. T. Strub (2001), Seasonal climatology of hydrographic conditions in the upwelling region off northern Chile, J. Geophys. Res., 106, 11,451-11,467.

Brink, K. H., R. C. Beardsley, P. P. Niiler, M. Abbott, A. Huyer, S. Ramp, T. Stanton, and D. Stuart (1991), Statistical properties of near-surface flow in the California coastal transition zone, J. Geophys. Res., 96, 14,693-14,706.

Colin de Verdiere, A. (1983), Lagrangian eddy statistics from surface drifters in the eastern North Atlantic, J. Mar. Res., 41, 375-398.

Cushman-Roisin, B. (1994), Introduction to Geophysical Dynamics, 320 pp., Prentice-Hall, Upper Saddle River, N. J.

Davis, R. E. (1987), Modeling eddy transport of passive tracers, J. Mar. Res., 45, 635-666.

Davis, R. E. (1991), Observing the general circulation with floats, Deep Sea Res., 38, S531-S571.

Ducet, N., P. Y. Le Traon, and G. Reverdin (2000), Global high-resolution mapping of ocean circulation from TOPEX/Poseidon and ERS-1 and -2, J. Geophys. Res., 105, 19,477-19,498.

Flierl, G. R., and J. C. McWilliams (1977), On the sampling requirements for measuring moments of eddy variability, J. Mar. Res., 35, 797-820.

Freeland, H. J., P. B. Rhines, and H. T. Rossby (1975), Statistical observations of the trajectories of neutrally buoyant floats in the North Atlantic, J. Mar. Res., 33, 383-404.

Hansen, D. V., and P.-M. Poulain (1996), Quality control and interpolations of WOCE-TOGA drifter data, J. Atmos. Oceanic Technol., 13, 900-909.

Hormazabal, S., G. Shaffer, and O. Leth (2004), Coastal transition zone off Chile, J. Geophys. Res., 109, C01021, doi:10.1029/2003JC001956.

Knudsen, J. G., and D. L. Katz (1958), Fluid Dynamics and Heat Transfer, 576 pp., McGraw-Hill, New York.

Krauss, W., and C. W. Böning (1987), Lagrangian properties of eddy fields in the northern North Atlantic as deduced from satellite-tracked buoys, J. Mar. Res., 45, 259-291.
Kundu, P., and I. Cohen (2000), Fluid Mechanics, 2nd ed., 730 pp., Elsevier, New York.

Leth, O., and G. Shaffer (2001), A numerical study of the seasonal variability in the circulation off central Chile, J. Geophys. Res., 106, 22,229-22,248.

Leth, O., G. Shaffer, and O. Ulloa (2004), Hydrography of the eastern South Pacific Ocean: Results from the Sonne 102 Cruise, May-June 1995, Deep Sea Res., Part II, 51, 2349-2369.

Le Traon, P.-Y., and R. Morrow (2001), Ocean currents and eddies, in Satellite Altimetry and Earth Sciences: A Handbook of Techniques and Applications, edited by L.-L. Fu and A. Cazenave, 457 pp., Elsevier, New York.

Le Traon, P.-Y., and F. Ogor (1998), ERS-1/2 orbit improvement using TOPEX/Poseidon: The $2 \mathrm{~cm}$ challenge, J. Geophys. Res., 103, 80458057.

Le Traon, P.-Y., P. Gaspar, F. Ogor, and J. Dorandeu (1995), Satellites work in tandem to improve accuracy of data, Eos Trans. $A G U, 76$, $385-389$.

Lumpkin, R., and P. Flament (2001), Lagrangian statistics in the central North Pacific, J. Mar. Syst., 29, 141-155.

Martins, C. S., M. Hamann, and A. F. G. Fiúza (2002), Surface circulation in the eastern North Atlantic, from drifters and altimetry, J. Geophys. Res., 107(C12), 3217, doi:10.1029/2000JC000345.

Mofjeld, H. O., and J. W. Lavelle (1984), Setting the length scale in a second-order closure model of the unstratified bottom boundary layer, J. Phys. Oceanogr., 14, 833-839.

Morrow, R., J. Church, R. Coleman, D. Chelton, and N. White (1992), Eddy momentum flux and its contribution to the Southern Ocean momentum balance, Nature, 357, 482-484.

Morrow, R., R. Coleman, J. Church, and D. Chelton (1994), Surface eddy momentum flux and velocity variances in the Southern Ocean from Geosat altimetry, J. Phys. Oceanogr., 24, 2050-2071.

Niiler, P. P., and J. D. Paduan (1995), Wind-driven motions in the northeast Pacific as measured by Lagrangian drifters, J. Phys. Oceanogr., 25, 2819-2830.

Niiler, P. P., A. S. Sybrandy, K. Bi, P.-M. Poulain, and D. Bitterman (1995), Measurements of the water-following capability of holey-sock and TRISTAR drifters, Deep Sea Res., Part I, 42, 1951-1964.

Oh, I. S., V. Zhurbas, and W. Park (2000), Estimating horizontal diffusivity in the East Sea (Sea of Japan) and the northwest Pacific from satellitetracked drifter data, J. Geophys. Res., 105, 6483-6492.

Pizarro, O. (1999), Low frequency fluctuations in the eastern boundary current off South America: Remote and local forcing, Ph.D. thesis, Göteborg Univ., Sweden.

Pizarro, O., G. Shaffer, B. Dewitte, and M. Ramos (2002), Dynamics of seasonal and interanual variability of the Peru-Chile Undercurrent, Geophys. Res. Lett., 29(12), 1581, doi:10.1029/2002GL014790.

Poulain, P.-M., and P. P. Niiler (1989), Statistical analysis of the surface circulation in the California Current system using satellite-tracked drifters, J. Phys. Oceanogr., 19, 1588-1603.

Preisendorfer, R. W. (1988), Principal Component Analysis in Meteorology and Oceanography, 245 pp., Elsevier, New York.

Richman, J. G., C. Wunsch, and N. G. Hogg (1977), Space and time scales and mesoscale motions in the sea, Rev. Geophys., 15, 385-420.

Shaffer, G., S. Salinas, O. Pizarro, A. Vega, and S. Hormazabal (1995), Currents in the deep ocean off Chile $\left(30^{\circ} \mathrm{S}\right)$, Deep Sea Res., 42, 425436.

Shaffer, G., O. Pizarro, L. Djurfeldt, S. Salinas, and J. Rutlant (1997), Circulation and low frequency variability near the Chile coast: Remotelyforced fluctuations during the 1991-1992 El Niño, J. Phys. Oceanogr., 27, $217-235$

Shaffer, G., S. Hormazabal, O. Pizarro, and S. Salinas (1999), Seasonal and interannual variability of currents and temperature off central Chile, J. Geophys. Res., 104, 29,931-29,961.

Shaffer, G., S. Hormazabal, O. Pizarro, and M. Ramos (2004), Circulation and variability in the Chile basin, Deep Sea Res., Part I, 51, 13671386.

Silva, N., and T. R. Fonseca (1983), Geostrophic component of the oceanic flow off northern Chile, in Resursos Marinos del Pacifico, edited by P. Arana, pp. 59-70, Escuela de Cienc. del Mar, Univ. Católica de Valparaíso, Chile.

Stammer, D. (1997), Global characteristics of ocean variability estimated from regional TOPEX/POSEIDON altimeter measurements, J. Phys. Oceanogr., 27, 1743-1769.

Stammer, D. (1998), On eddy characteristics, eddy transports, and mean flow properties, J. Phys. Oceanogr., 28, 727-739.

Stigebrandt, A. (1985), A model of the seasonal pycnocline in rotating systems with application to the Baltic Proper, J. Phys. Oceanogr., 15, $1392-1404$.

Stramma, L., R. G. Peterson, and M. Tomczak (1995), The South Pacific Current, J. Phys. Oceanogr., 25, 77-91. 
Strub, P. T., J. M. Mesías, and C. James (1995), Altimeter observations of the Peru-Chile Countercurrent, Geophys. Res. Lett., 22, 211-214.

Strub, P. T., J. M. Mesias, V. Montecino, J. Rutllant, and S. Salinas (1998), Coastal ocean circulation off western South America, in The Sea, vol. 11, edited by A. R. Robinson and K. H. Brink, pp. $273-$ 313, John Wiley, Hoboken, N. J.

Swenson, M. S., and P. P. Niiler (1996), Statistical analysis of the surface circulation of the California Current, J. Geophys. Res., 101, 22,63122,645 .

Taylor, G. I. (1921), Diffusion by continuous movements, Proc. London Math. Soc., 20, 196-211.

Tomczak, M., and J. S. Godfrey (1994), Regional Oceanography: An Introduction, 442 pp., Elsevier, New York.

Tsuchiya, M., and L. D. Talley (1998), A Pacific hydrographic section at $88^{\circ} \mathrm{W}$ : Water-property distribution, J. Geophys. Res., 103, 12,89912,918 .

Vega, A. (2003), Ondes de Rossby, niveau de la mer et couleur de l'eau dans le Pacifique Sud-Est, Ph.D. thesis, 160 pp., Univ. é Paul Sabatier de Toulouse, France.

Wilkin, J. L., and R. A. Morrow (1994), Eddy kinetic energy and momentum flux in the Southern Ocean: Comparison of a global eddy-resolving model with altimeter, drifter, and current-meter data, J. Geophys. Res., 99, 7903-7916

Wooster, W. S. (1970), Eastern boundary currents in the South Pacific, in Scientific Exploration of the South Pacific, edited by W. S. Wooster, pp. $60-68$, Natl. Acad. of Sci., Washington, D. C.
Wyrtki, K. (1964), Total integrated mass transports and actual circulation in the eastern South Pacific Ocean, in Studies in Oceanography, pp. 47-52, Japan.

Zamudio, L., A. P. Leonardi, S. D. Meyers, and J. J. O'Brien (2001), ENSO and eddies on the southwest coast of Mexico, Geophys. Res. Lett., 28, $13-16$.

Zhang, H.-M., M. D. Prater, and T. Rossby (2001), Isopycnal Lagrangian statistics from the North Atlantic Current RAFOS float observations, J. Geophys. Res., 106, 13,817-13,836.

Zhurbas, V., and I. S. Oh (2003), Lateral diffusivity and Lagrangian scales in the Pacific Ocean as derived from drifter data, J. Geophys. Res., 108(C5), 3141, doi:10.1029/2002JC001596.

Zhurbas, V., and I. S. Oh (2004), Drifter-derived maps of lateral diffusivity in the Pacific and Atlantic Oceans in relation to surface circulation patterns, J. Geophys. Res., 109, C05015, doi:10.1029/2003JC002241.

A. Chaigneau, Programa Regional de Oceanografía Física y Clima, Cabina 7, Universidad de Concepción, Concepción, Chile. (chaigneau@ profc.udec.cl)

O. Pizarro, Departamento de Geofísica/Centro de Investigación Oceanográfica en el Pacífico Sur-Oriental, Universidad de Concepción, Casilla 160-C, Concepción, 3, Chile. (orpa@profc.udec.cl) 